\title{
BIOGEOGRAPHY OF THE AREAS AND CANTHONINI (COLEOPTERA: SCARABAEIDAE) OF DRY TROPICAL FORESTS IN MESOAMERICA AND COLOMBIA
}

\author{
Dora Nancy Padilla-GiL and Gonzalo Halffter \\ Instituto de Ecología, A.C., Apdo. Postal 63, 91000 Xalapa, Veracruz, MEXICO \\ dnpadilla@hotmail.com, gonzalo.halffter@inecol.edu.mx
}

\begin{abstract}
RESUMEN
Este análisis biogeográfico examina los procesos históricos, geológicos, climáticos y ecológicos que han influido en la formación de los bosques tropicales secos (DTF) de Mesoamérica y Colombia, bosques que son sitios de múltiples historias biogeográficas como la que ilustran los Canthonini. Sometemos a prueba la hipótesis de que la fauna de Canthonini de los bosques tropicales secos tiene una afinidad sudamericana. Para este propósito comparamos las especies que se encuentran en un enclave de bosque tropical seco en México, en un segundo enclave en Costa Rica, en cuatro de la región Caribe de Colombia y finalmente uno más en el norte de Tolima en el valle superior del río Magdalena, Colombia. Las características geomorfológicas de los enclaves son también comparadas, así como la distribución geográfica y las afinidades taxonómicas de cada una de las especies de Canthonini que se encuentran en estos bosques tropicales secos. Los aspectos de historia biogeográfica, geológica y ecológica de los enclaves son evaluados usando un Análisis de Parsimonia de Endemicidad (PAE), utilizando como grupo externo dos lugares de selva siempre verde: Leticia (Amazonas, Colombia) y Los Tuxtlas (Veracruz, México). Este estudio pone de manifiesto que el origen y distribución de los bosques tropicales secos de la región ocurre durante el Pleistoceno, con una acentuación de las características de sequía durante el Holoceno. También revela similitudes entre los Canthonini de los bosques tropicales secos de México, Costa Rica y Colombia, con tres patrones de distribución que corresponden a diferentes grados de expansión hacia el norte y a la diversificación de líneas evolutivas, incluso a la presencia de especies sudamericanas.
\end{abstract}

La comparación entre el cladograma generado por las especies de Canthonini y el de eventos geológicos, indica que la distribución de los primeros en los bosques tropicales secos comienza en el Plioceno con el restablecimiento de la conexión panameña, sin evidencias de que eventos geomorfológicos previos hayan ejercido influencias. Por otra parte, hay muy pocas especies compartidas con las selvas siempre verdes usadas como grupo externo en los cladogramas.

Palabras Clave: Scarabaeinae, Canthonini, bosque tropical seco, México, Costa Rica, Colombia, patrones biogeográficos.

ABSTRACT

This biogeographical analysis examines the historical, geological, climatic and ecological processes that have influenced the formation of the dry tropical forests (DTF) of Mesoamerica and Colombia, areas that are the setting for multiple biogeographical stories that in this case are illustrated by the patterns and evolutionary processes of Canthonini. In this study we test the hypothesis that the Canthonini fauna of dry tropical forests has a South American affinity. To this end, we compare extant species from a tract of dry tropical forest in Mexico, a second enclave in Costa Rica, four from the Caribbean region of Colombia and finally one from the north of Tolima in the Upper Magdalena River Valley, Colombia. The geomorphological characteristics of the enclaves of DTF are also compared, as are the geographical distribution and 
Padilla-Gil \& Halffter: Biogeography of Canthonini in Mesoamerica and Colombia

taxonomic affinities of each of the species found in these dry tropical forests. The biogeographical, historical and geological aspects of the enclaves were evaluated using a Parsimony Analysis of Endemicity (PAE), with two tropical rain forests as the outgroup: Leticia (Amazonas, Colombia) and Los Tuxtlas (Veracruz, Mexico).

This study reveals the origin and distribution of Neotropical dry forests in the Pleistocene, and the establishment of its dry conditions during the Holocene. It also reveals apparent similarities among the Canthonini of the dry tropical forests of Mexico, Costa Rica and Colombia, with three geographical distribution patterns that correspond to different degrees of expansion towards the north and the diversification of evolutionary lines, and even species of South American origin.

The comparison of the cladogram generated for species of Canthonini with that of the geological events that have occurred in the study regions indicates that the distribution of Canthonini in dry tropical forests began during the Pliocene with the re-establishment of the Panamanian connection, with no evidence of previous geomorphological events having any influence. On the other hand, there are few species shared with the tropical rain forests used as the outgroup for the cladograms.

Key Words: Scarabaeinae, Canthonini, dry tropical forest, Mexico, Costa Rica, Colombia, biogeographical patterns

\section{INTRODUCTION}

It has been suggested that tribe Canthonini (Scarabaeidae: Scarabaeinae) has an ancient Gondwanian distribution with high species richness in South America (Halffter 1974). In the Americas, the genus with the most species is Canthon, with 174 according to Halffter \& Martínez (1977) that are distributed from Argentina to Canada. The origin of Canthon and close genera appears to be northern South America where it reaches its greatest richness in phyletic lines and species, with an expansion of lines toward the periphery of Chile where it is barely represented (Halffter 1974, Rivera-Cervantes \& Halffter 1999). From South America, Central and North America were populated by elements of this tribe during two probable great expansion events (Halffter 1964, 1974, 1976, Kohlmann \& Halffter 1990). The first could have occurred before or during the Miocene and the second when the connection with South and Central America was re-established from the Pliocene to the Recent. In the phyletic lines that participated in the first expansion, although it is possible to identify the South American affinities at the level of genus, there was notable speciation in Mexico and the United States of America, followed in some cases by secondary expansion. For those phyletic lines that participated in the second expansion event, the affinities with northern South America are much more marked, although there was also in situ speciation.

The objective of this study is to test this biogeographical hypothesis. To that end, we chose to use the species of Canthonini that inhabit dry tropical forest (DTF). These were selected because they are the least studied Scarabaeinae fauna compared to their tropical rain forest (TRF) counterparts and also because their distribution, now discontinuous, has been much less interrupted in the recent past.

This hypothesis regarding the biogeographical history of the Canthonini (common for other groups of Scarabaeinae and, in general, for insects) has been tested in various ways. First, by establishing the similarity of the Canthonini present in a series of enclaves found in DTF in Mexico, Costa Rica and Colombia - places for which we have reliable 
lists of the fauna. Second, we have analyzed the historical and geological relationships of the regions where these enclaves are located in order to relate the history of the areas with both the phylogeny and the geographical distribution of Canthonini. Finally, the two previous points are integrated in order to recreate the setting of the DTF where the processes of speciation and dispersion of some Canthonini probably took place, and also to explain their geographic distribution. As proposed by Zunino (2005) we intend to compare the distribution and phylogenetic history of the taxa with the geography and geomorphological history of the areas to arrive at a comprehensive interpretation of the entire set of elements.

DTF, also known as tropical deciduous forest is defined as that formation of vegetation with a continuous woody cover distributed from sea level to $1000 \mathrm{~m}$, with mean temperatures above $24^{\circ} \mathrm{C}$ and precipitation ranging from 700 to $2000 \mathrm{~mm}$ per year (Espinal 1985; IAvH 1997a). This vegetation has woody species that lose their leaves during the dry season over a variable period of time that lasts around six months (Rzedowski 1978).

According to Rzedowski (1978) DTF is particularly characteristic of the Pacific Slope of Mexico, where it covers extensive areas almost uninterrupted from the south of Sonora and southwest of Chihuahua to Chiapas, continuing southwards in Central America. It penetrates deep into the Balsas and the Santiago River basins, as well as those of the tributaries of these rivers. In the Isthmus of Tehuantepec, DTF passes the watershed and occupies a good part of the Central Depression of Chiapas. On the Atlantic Slope there are at least three large patches of DTF and it is also found on the Yucatan Peninsula (see Trejo 2005).

In Mexico, DTF once covered 6 to $14 \%\left(270000 \mathrm{~km}^{2}\right)$ of the area in the country that lies between sea level and $1500 \mathrm{~m}$. DTF has been reduced to $27 \%$ of its original cover (Trejo \& Dirzo 2000). In Costa Rica almost all of the Nicoya Peninsula and Chira Island in the northeast of the country, were covered by this type of forest 100 years ago (Kohlmann et al. 2002). In Central America, DTF once covered $7 \%\left(33600 \mathrm{~km}^{2}\right)$ of the total area between 0 and $1000 \mathrm{~m}$. The remaining tropical dry forest in Central America probably represents less than $2 \%$ of the original (Sabogal \& Valerio 1998). Colombia has three large regions with DTF and the two largest are the Caribbean Plain, including southern Guajira and the Magdalena River Valley in the Departments of Tolima, Cundinamarca and Huila (IAvH 1997b). In Colombia the status of DTF is critical. It is estimated that only $1 \%$ of the original $80000 \mathrm{~km}^{2}$ of dry to subhumid forests remains (Etter 1993). Figure 1 summarizes the distribution of DTF in the study area.

The biogeography of the areas of dry tropical forest is undertaken with cladistic analysis, keeping in mind the past and present geological and geomorphological characteristics of the area. In order to understand the biogeographical relationships between the enclaves of DTF and the species of Canthonini, we used a Parsimony Analysis of Endemicity (PAE) that produces a hierarchical set of the species represented in the different areas, and associates it with the geological or ecological factors, or a combination thereof. PAE can provide the grounds for explaining: 1) the effects of geological events on evolution; 2) the effects of ecological factors on evolution; 3 ) the influence of geological events on ecological conditions and the evolutionary consequences of these; 4) distribution patterns, 
i.e. which sets of species can appear in different areas owing solely to events in geological history or the association of the latter with ecological conditions (Rosen 1988).

This study has two purposes, the first is to analyze the biogeographical history of the areas of dry tropical forest in Mesoamerica and Colombia based on their geomorphological characteristics and their geological origin; the second is to establish the relationships between these forests using the Canthonini as an indicator group, comparing their distribution with the geomorphological history of those areas and explaining the presence of Canthonini in dry forest.

First we carry out the biogeographical analysis of the neotropiocal dry forests that are the object of this study, and then the biogeographical analysis of the Canthonini. Some aspects of Canthonini in dry forest are discussed in light of other floristic, faunal, ecological and biogeographical elements that are particularly related to the Canthonini and the geographical limits of some species.

\section{MATERIALS AND METHODS}

\section{Study sites:}

The DTF sites we selected in Mesoamerica and Colombia are enclaves representative of the current distribution of this type of vegetation (Fig. 1). Chamela (Jalisco, Mexico) and Palo Verde (Guanacaste, Costa Rica) are located on the Pacific coast. In the Caribbean region of Colombia we selected four areas: Neguanje, Tierra Bomba, Los Colorados and Zambrano. In the Magdalena River Valley, we selected the DTF located in the north of the Department of Tolima. Two of the sites selected in the Caribbean region, Los Colorados and Neguanje, have the highest floristic richness, basal area and canopy height of the DTF found in the Caribbean and Tolima region (Mendoza 1999). Another factor which led to the selection of these sites was the availability of information on the Scarabaeinae fauna. There are publications for each of the sites, and there are also databases for Costa Rica (INBio) and Mexico (SNIB-CONABIO). The sites are described below together with the most relevant features associated to geological and geomorphologic characters (see Tables 1 and 2).

Chamela, Jalisco, Mexico. The Chamela-Cuixmala Biosphere Reserve is located on the Pacific coast (19 $\left.30^{\prime} \mathrm{N}, 105^{\circ} 03^{\prime} \mathrm{W}\right)$. The study site is between the San Nicolas River in the north and the Cuixmala River in the south, centred in the surroundings of the Chamela Biological Station (Fig. 1). With altitudes lower than $200 \mathrm{~m}$, the climate has no marked seasonality with respect to temperature. Mean monthly maxima range from 28.8 to $32.2^{\circ} \mathrm{C}$, and the minima from 15.9 to $22.6^{\circ} \mathrm{C}$. Mean annual precipitation is $707 \mathrm{~mm}$. The rainy season lasts four months on average, starting at the beginning of July and ending at the beginning of November (Bullock 1988).

Chamela belongs to the Jalisco Block (JB), which constitutes a tectono-stratigraphic assemblage from the Late Cretaceous to Early Tertiary (Paleocene), with volcanic and volcaniclastic deposits and marine sedimentary sequences intruded by granitoid plutons. The plutonic and volcanic rocks of the JB are part of the magmatic arc, which is found 
southeastward along the terrain of the state of Guerrero. On the other hand, Chamela is aseismic and is located on the North American tectonic plate. It is characterized by an undulating landscape, the presence of mineral, soil with low permeability and organic matter.

Palo Verde, Guanacaste, Costa Rica. The Palo Verde Biological Station (Fig. 1) is located in the Palo Verde National Park ( $\left.10^{\circ} 20^{\prime} \mathrm{N}, 85^{\circ} 18^{\prime} \mathrm{W}\right)$ on the Pacific slope, in the Province of Guanacaste and halfway up the basin of the Tempisque River at an altitude of

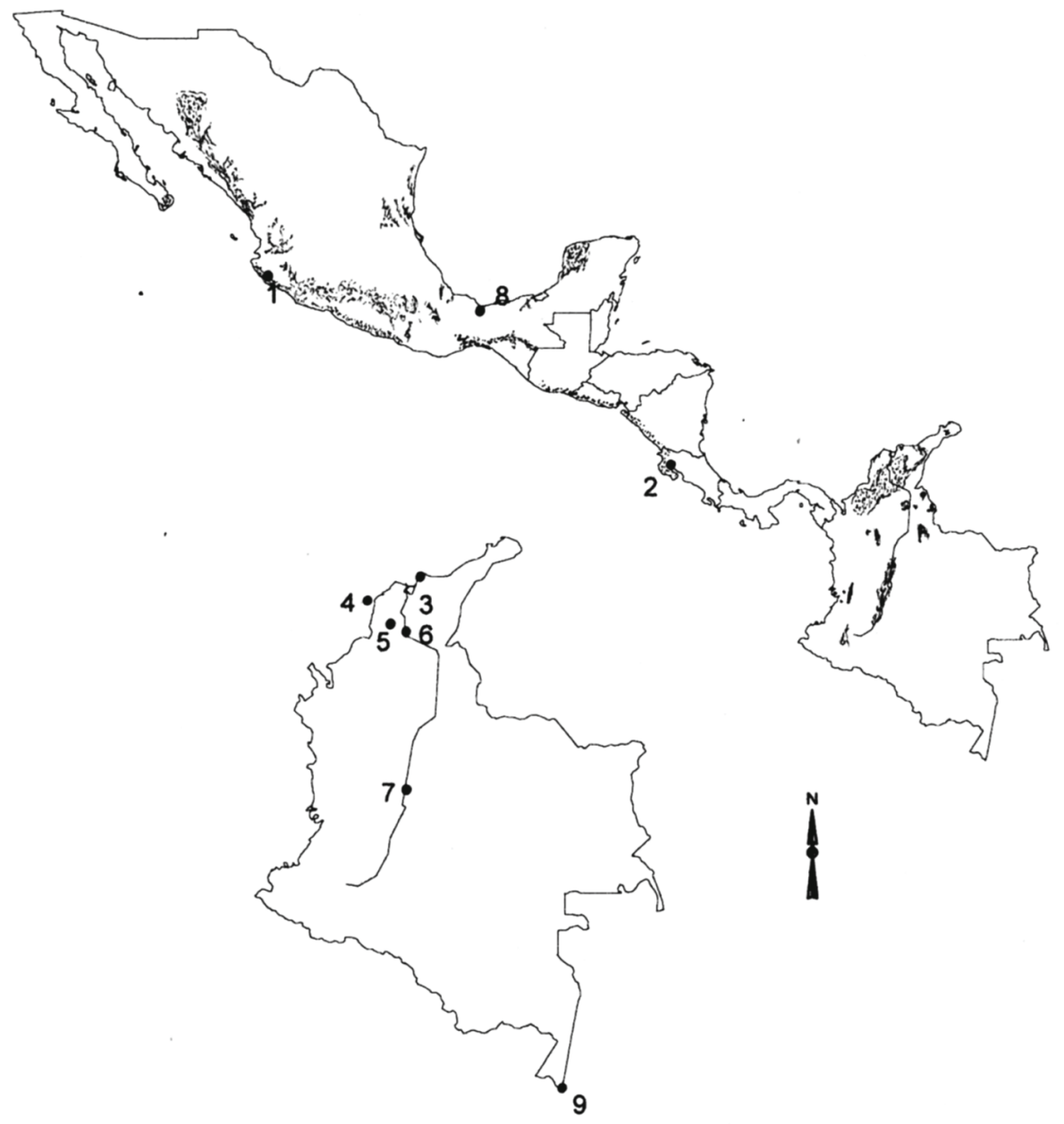

Figure 1

Study sites, DTF (1- 7): 1 = Chamela, 2 = Palo Verde, $3=$ Neguanje, $4=$ Tierra Bomba, $5=$ Los Colorados, 6 = Zambrano, 7 = Norte del Tolima; TRF (8-9): $8=$ Los Tuxtlas, $9=$ Leticia (Amazonas). The dotted area corresponds to the distribution of DFT, based on Gómez (1982); IAvH (1997 b), CONABIO (1990) and Trejo \& Dirzo (2002). 
Padilla-Gil \& Halffter: Biogeography of Canthonini in Mesoamerica and Colombia

Table 1

Bibliography consulted for the selection of geomorphological characters.

\begin{tabular}{|c|c|}
\hline Mexico & $\begin{array}{l}\text { López-Ramos 1980, Bullock 1988, Bandy et al. 1999, Ferrari et al. 1999, Ferrari \& } \\
\text { Rosas-Elguera 1999, Rutz 2002, Campo-Alves 2003, Hernández-Quintero 2003, } \\
\text { Sommer-Cervantes et al. } 2003 .\end{array}$ \\
\hline Costa Rica & $\begin{array}{l}\text { Schmidt-Effing 1980, Rich \& Rich 1983, Vásquez 1983, Alvarado et al. 1986, } \\
\text { Chiesa et al. 1994, Henríquez et al. 1994, Meschede et al. 2000, Nelson \& Nietzen } \\
\text { 2000, Alfaro et al. 2001, Jaccard et al. 2001, Montero 2001, Cuevas et al. } 2003 .\end{array}$ \\
\hline Colombia & $\begin{array}{l}\text { Taborda 1950, Rubio et al. 1977, Galvis et al. 1979, Aucott 1983, González et al. } \\
\text { 1988, Malagón 1988, Sánchez et al. 1998, Sánchez-Valbuena 1992, París \& } \\
\text { Romero 1994, Giunta et al. 1996, Molina 1996, Herrera et al. 2001, Ramón et al. } \\
\text { 2001, Caro \& Spratt 2003. }\end{array}$ \\
\hline & $\begin{array}{c}\text { Table } 2 \\
\text { Geological-geomorphological characters and their states }\end{array}$ \\
\hline \multicolumn{2}{|c|}{ 1. Land profile. undulating (0), valley (1), flat (2) } \\
\hline \multicolumn{2}{|c|}{ 2. Potassium. low (0), optimal (1) } \\
\hline \multicolumn{2}{|c|}{ 3. Organic material in the soil. high (1), low (0) } \\
\hline \multicolumn{2}{|c|}{$\begin{array}{l}\text { 4. Most abundant minerals in the sandy fraction of the soils. feldspar (0), quartz (1), } \\
\text { olivine- pyroxene (2), amphiboles ( } 3 \text { ) }\end{array}$} \\
\hline \multicolumn{2}{|c|}{ 5. Tectonic plate. Caribe (0), North America (1), South America (2) } \\
\hline \multicolumn{2}{|c|}{ 6. Seismicity. high (0), low-absent (1) } \\
\hline \multicolumn{2}{|c|}{ 7. Faults. present (0), absent (1) } \\
\hline \multicolumn{2}{|c|}{ 8. Geological era. Mesozoic (0), Tertiary (1), Quaternary (2) } \\
\hline \multicolumn{2}{|c|}{$\begin{array}{l}\text { 9. Geological period. Middle Jurassic- Late Cretaceous (0), Eogene [Oligocene, } \\
\text { Eocene, Paleocene] (1), Neogene [Pliocene, Miocene] (2), Pleistocene, Holocene (3) }\end{array}$} \\
\hline \multicolumn{2}{|c|}{ 10. Magnetism. low (0), high (1) } \\
\hline \multicolumn{2}{|c|}{ 11. Type of rock. sedimentary (0), igneous (1), metamorphic (2) } \\
\hline \multicolumn{2}{|c|}{ 12. Nearby volcanic range. present (0), absent (1) } \\
\hline \multicolumn{2}{|c|}{ 13. Soil permeability. high to moderate (0), low (1) } \\
\hline \multicolumn{2}{|c|}{ 14. Origin of rock. marine (0), continental (1) } \\
\hline \multicolumn{2}{|c|}{$\begin{array}{l}\text { 15. Evolution of the soil profile. zoned (highly evolved) (0), not zoned (young or slightly } \\
\text { developed) (1) }\end{array}$} \\
\hline \multicolumn{2}{|c|}{ 16. Origin of the plate. Paleozoic (0), Mesozoic (1) } \\
\hline \multicolumn{2}{|c|}{ 17. Metals. Ag, Pt, Au, Fe. absent (0), presente (1) } \\
\hline 18. Bougu & r's anomalies (gravimetric anomalies). positive (0), negative (1) \\
\hline
\end{tabular}


10 to $50 \mathrm{~m}$. Mean annual temperature ranges from 24.0 to $27.8^{\circ} \mathrm{C}$ and mean annual precipitation is $1750 \mathrm{~mm}$ (Quigley \& Platt 2003), with a 6.5 month long dry season each year (SIEPAC 2003).

It is characterized by an undulating landscape, with slightly developed soils, and the most abundant minerals are olivine-pyroxene. The local fault is responsible for the seismicity. The Palo Verde region dates from the Paleocene to Early Eocene. This site is characterized by high magnetism, and is located on the Caribbean tectonic plate

Colombia, Caribbean Region. The sites selected (Fig. 1) have been described by Mendoza (1999). Located between 50 and $300 \mathrm{~m}$, their mean temperatures are greater than $24^{\circ} \mathrm{C}$ and they receive 700 to $2000 \mathrm{~mm}$ of precipitation per year. There are two marked dry seasons per year (IAvH 2000). This region is represented by four sites:

a) Zambrano: Forest Reserve, Monterrey. Located in the Departament of Bolivar, Zambrano Municipality ( $\left.9^{\circ} 37^{\prime} 48^{\prime \prime} \mathrm{N}, 74^{\circ} 54^{\prime} 44^{\prime \prime} \mathrm{W}\right)$ at $155 \mathrm{~m}$. Mean annual precipitation is $1048 \mathrm{~mm}$.

b) Los Colorados. Located in the Departament of Bolivar, San Juan de Nepomuceno Municipality ( $\left.9^{\circ} 51^{\prime} 33^{\prime \prime} \mathrm{N}, 75^{\circ} 06^{\prime} 38^{\prime \prime W}\right)$, at $300 \mathrm{~m}$. Mean annual precipitation is 1189 $\mathrm{mm}$. This remnant of DTF belongs to the Los Colorados Flora and Fauna Sanctuary Conservation Unit.

c) Tierra Bomba Island. Located in the Department of Bolivar, Cartagena Municipality $\left(10^{\circ} 21^{\prime} 36^{\prime \prime} \mathrm{N}, 75^{\circ} 34^{\prime} 11^{\prime \prime} \mathrm{W}\right)$, at $50 \mathrm{~m}$. Mean annual precipitation is $789 \mathrm{~mm}$.

d) Neguanje. Located in the Department of Magdalena, in the Santa Marta Municipality $\left(11^{\circ} 18^{\prime} 05^{\prime \prime} \mathrm{N}, 74^{\circ} 06^{\prime} 11^{\prime \prime} \mathrm{W}\right)$ at $300 \mathrm{~m}$. Mean annual precipitation is $1420 \mathrm{~mm}$. Neguanje belongs to the Tayrona National Park.

The Caribbean Region is located between the Perijá to the east and the Sierra Nevada. On the surface, fluvial and lacustrine sediments from the Quaternary predominate. It is characterized by a sequence of sandy, slime and clay, and feldspar is the most abundant mineral in the sandy fraction of the soil. It is aseismic and located on the Caribbean tectonic plate. In geological terms, Neguanje belongs to the geotectonic province of Santa Marta (land originating in the Mesozoic: Middle Jurassic to Late Cretaceous) and the other three sites belong to the province of the Caribbean Plain. Zambrano belongs to the San Jorge-Plato geostructure (the land dates from the Quaternary), Los Colorados to the San Jacinto Belt (the land dates from the Tertiary: Late Eocene) and Cartagena to the Sinú Belt (Tierra Bomba is from the Quaternary). The Sierra Nevada is associated with the Santa Marta fault and the Caribbean Plain is associated with the Romeral system fault in the west.

North Tolima. We selected the study area described by Escobar (1997). It is located on the east side bank of the Magdalena River (Fig. 1), $130 \mathrm{~km}$ from the city of Ibagué in the jurisdiction of the municipalities of Honda, Armero-Guayabal and Piedras, at $\left(4^{\circ} 15^{\prime}-5^{\circ}\right.$ $10^{\prime} \mathrm{N}, 74^{\circ} 45^{\prime}-74^{\circ} 50^{\prime} \mathrm{W}$ ) at $250 \mathrm{~m}$. Mean annual precipitation is $1387 \mathrm{~mm}$ and the mean annual temperature is $28^{\circ} \mathrm{C}$, with two well defined dry periods, one from December to March and the other from June to August.

North Tolima forms part of the Upper Magdalena River Valley, an inter-Andina valley on the eastern slope of the Cordillera Central. It belongs to the Honda formation dating 
Padilla-Gil \& Halffter: Biogeography of Canthonini in Mesoamerica and Colombia

from the Tertiary: Miocene. There are faults nearby and it is associated with the Plioquaternary volcanic activity of the Cordillera Central, as reflected in its notable seismicity. Los Tuxtlas, Veracruz, Mexico. The Los Tuxtlas Biological Station is located in the foothills of the San Martin Volcano, $19 \mathrm{~km}$ north of the city of Catemaco in the state of Veracruz (Fig. 1; $18^{\circ} 34^{\prime}-18^{\circ} 36^{\prime} \mathrm{N}, 9^{\circ} 04^{\prime}-95^{\circ} 09^{\prime} \mathrm{W}$ ) at 150 to $530 \mathrm{~m}$. Mean annual precipitation is $4560 \mathrm{~mm}$ and the mean annual temperature is $23.7^{\circ} \mathrm{C}$ (Morón 1979).

Los Tuxtlas Reserve belongs to the formation La Laja, which dated Oligocene and is located on the North American tectonic plate. It is characterized by an undulating landscape, igneous rocks of continental origin, nearby mountains, soils with high permeability and organic material, and high seismicity.

Leticia, Amazonas, Colombia. The Colombian Amazon has a humid tropical climate. The site is located at $4^{\circ} 8^{\prime} \mathrm{S}, 70^{\circ} 1^{\prime} \mathrm{W}$, and $96 \mathrm{~m}$ (Fig. 1). Mean annual precipitation is $3500 \mathrm{~mm}$, with the majority of the rain falling between April and June. Mean annual temperature is $26^{\circ} \mathrm{C}$, with maximum temperatures in October and November $35^{\circ} \mathrm{C}$. It is cooler in July with minima from 20 to $25^{\circ} \mathrm{C}$ (Galvis et al. 1979).

It is characterized by an undulating landscape, with highly evolved soils, a limited presence of minerals and low levels of natural fertility. Quartz dominated more than $90 \%$ of the sandy fraction and potassium was scarce. This geomorph developed over sedimentary rocks with a thick grain. The Quaternary deposits are comprised of sand, possibly of eolic origin, with recent terraces and alluvial deposits. This is an aseismic region located on the South American plate.

\section{Ingroup and Outgroup}

Our decision to use a real outgroup is based on the fact that the rain forest provides ecological characteristics that contrast with those of dry forest and take into account the previous hypotheses about its probable origin in neotropical forest. Also, rain forest is supposed to be older than dry forest (see Sarmiento 1975, Platt et al. 1981, Gentry 1982, Hooghiemstra \& Van der Hammen 2001, Richardson et al. 2001, Hooghiemstra et al. 2002, Graham 2003). The use of an outgroup provides both a geographical context and vegetation formations that contrast with the characteristics of the areas where the Scarabaeinae we are studying are currently found.

\section{Geomorphological cladogram}

Historical and geomorphological relationships were analyzed following Craw (1988). The seven dry forests make up the ingroup, however our analysis differs because for the outgroup we have used real sites of tropical rain forest, instead of coding for the outgroup with zeros. The rain forests selected carrying out the analysis using this outgroup allows the cladogram to be polarized and hence produces the more parsimonious solution than one that uses zeros.

In order to select characters and assign character states for each of the sites, more than fifty references were consulted. The list of the main studies consulted is presented by country in Table 1.

The geologic-geomorphological characters provide evidence from different sources of characters: geomorphostructural, geophysical and edaphic. The geomorphostructural 
characteristics of the terrain are defined by its geological and morphostructural history (origin and evolution) and by the lithological composition of the materials. Geophysical characters include the geotectonic, magnetic and gravimetric anomalies of the physiographical regions. On the other hand, the origin of the soil is influenced by the relative material, relief, climate and the organisms that are present.

Eighteen characters and their states were selected (Tables 2, 3). Ambiguous characters were discarded as were those for which there is insufficient information for more than two sites. All the characters were given equal weight, with three ordered characters: 8, 9 and 16. These characters were taken as unordered because they are related to chronological sequences of events associated to the scale of geological time.

\section{Cladogram of the areas of affinity for the Canthonini}

The relationships of DTF were analyzed using Parsimony Analysis of Endemicity (PAE), where the taxa are analogous to the sites and the characters to the species. In contrast to the methodology proposed by Rosen (1988) where the cladogram is rooted in a hypothetical ancestral area coded in zeros, here we use an external group, the outgroup, of real sites. The ingroup and outgroup are the same as mentioned for the previous analysis.

We chose PAE because it allows for the use of an outgroup in the analysis, the polarization of the cladogram, the addition of taxonomic hierarchies and it has a small data matrix.

A cladogram of the areas was generated using lists of the species (Table 4) present in each forest, indicating presence (1) or absence (0) according to the matrix (Table 5). Given that 24 of the 28 species belong to the genus Canthon, the subgenera of this taxon were included. The PAUP 4.0b10 (Swofford 2002) program with Acctran optimization and exhaustive search was used. The results were analyzed based on the majority consensus tree as it offered the greatest resolution.

Table 3

Matrix with character states for the cladogram of geomorphological areas.

\begin{tabular}{ll}
\hline & 123456789012345678 \\
\hline Leticia (C) & 000121123001010000 \\
Neguanje (C) & 210301000120110100 \\
Zambrano (C) & 210001123101110101 \\
Los Colorados (C) & 210001011101100101 \\
T. Bomba (C) & 210001123101000100 \\
N. Tolima (C) & 110020012100100010 \\
Chamela (M) & 010011011010111010 \\
Los Tuxtlas (M) & 001210111010011000 \\
P. Ve rde (CR) & 011200011110101100 \\
\hline
\end{tabular}


Padilla-Gil \& Halffter: Biogeography of Canthonini in Mesoamerica and Colombia

Table 4

List of Canthonini species from the study forests. Numbers are those used in the matrix of Table 5. The subgenera of the genus Canthon are Glaphyrocanthon (GI.), Canthon (C.), Goniocanthon (G.).

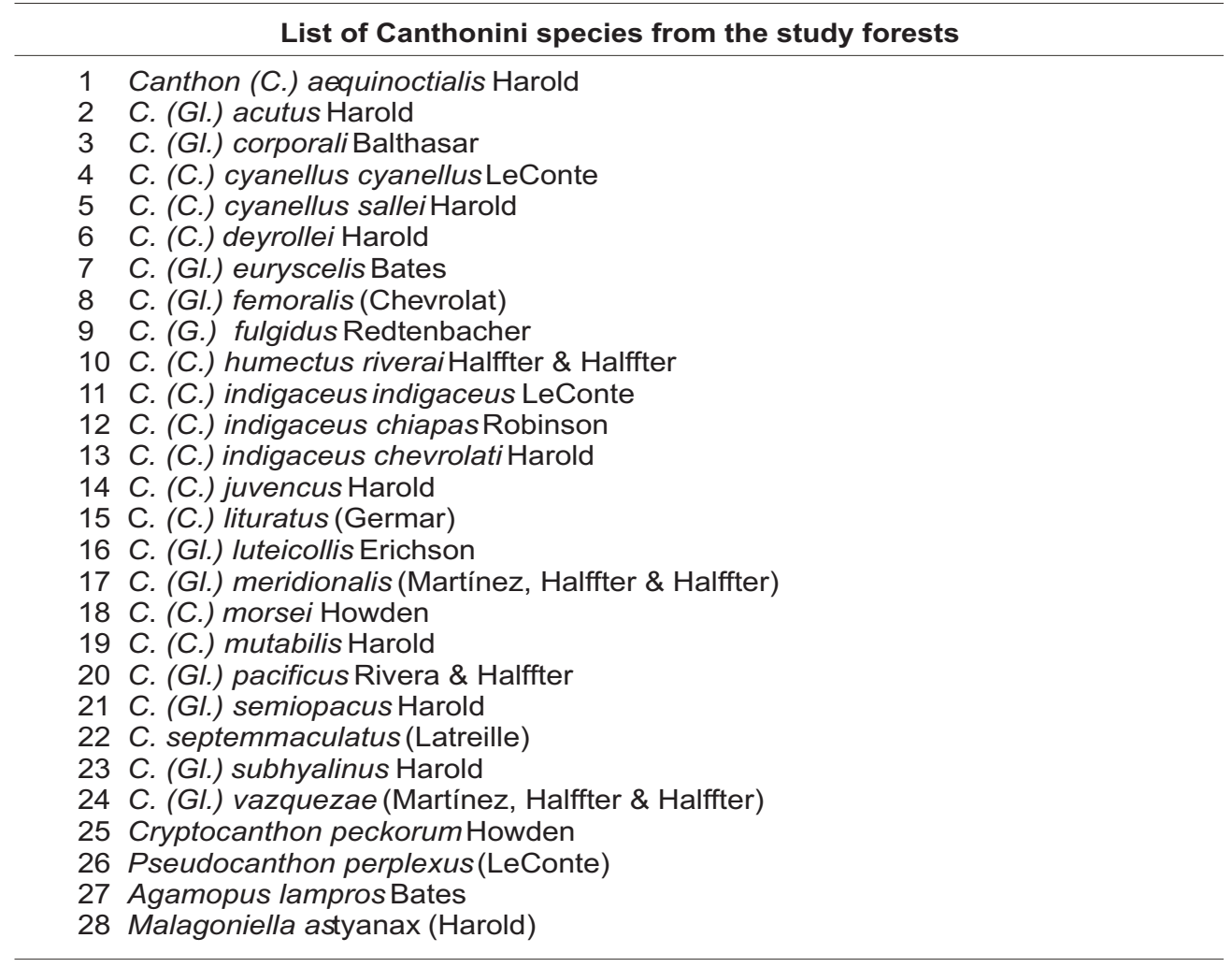

\section{List of Canthonini species from the study forests}

Table 5

Data matrix for the cladogram of the Canthonini areas

\begin{tabular}{ll}
\hline & 12345678901234567890123456789012 \\
\hline Chamela (M) & 00110000011000000001000001101001 \\
Los Tuxtlas (M) & 00010011000100000100001101001001 \\
P. Verde (CR) & 00001110000010001100000001111001 \\
N. Tolima (C) & 11001000000001100110001000011001 \\
Zambrano (C) & 00001000000001100000010000011010 \\
Los Colorados (C) & 10001000000001000000001000101001 \\
T. Bomba (C) & 00001000000001100000000000001000 \\
Neguanje (C) & 00001000000001100000000000001000 \\
Leticia (C) & 10000000100000010000100010001101
\end{tabular}




\section{Canthonini Species}

All the genera of Canthonini present in the forests studied are included in the analysis, with the exception of Deltochilum for which there is insufficient taxonomic and biogeographical information.

In order to compile the lists for Palo Verde and the Mexican site, in addition to a review of the publications mentioned below, the following data bases were used: INBio (Costa Rica) and SNIB-CONABIO (Mexico). The following publications were consulted: Chamela - Morón et al. (1988), Andresen (2005); Palo Verde - Kohlmann \& Wilkinson (2003); North Tolima Escobar (1997), Bustos-Gómez \& Lopera-Toro (2003); Caribbean Region of Colombia - Escobar $(1998,2000 a)$; species lists for these Colombian sites were also provided by F. Escobar; Leticia - list compiled by Bruce Gill, 12, I, 1997 with material collected by Howden \& Nealis (1975), Escobar (2000a), Medina et al. (2001); Los Tuxtlas - Morón (1979), Halffter et al. (1992), Favila \& Díaz (1997), Deloya \& Morón (1998), Díaz (1998, 2003).

Canthon deyrollei was described by Harold in 1868 , with the type locality unknown. It has been included for Colombia, without any other data in numerous publications (Vulcano \& Pereira 1964, Howden \& Young 1981, Solis \& Kohlmann 2002). In the publications that we consulted for Colombia this species is either not recorded or is not assigned a locality. Hence, the record for Colombia was not included.

Canthon cyanellus and $C$. indigaceus are included in the analysis with their respective subspecies according to Halffter (1961).

\section{Geographical distribution of Canthonini}

There are many studies that include the geographical distribution of Canthonini in Mexico. Some of those that we consulted for this study are: Halffter 1961, 1964, 1976; Martínez et al.1964; Halffter \& Matthews 1966; Barrera 1969; Martínez \& Halffter 1972; Morón \& Terrón 1984; Morón et al. 1985, 1986; Deloya et al. 1987; Delgado 1989; Kohlmann \& Halffter 1990; Palacios-Ríos et al. 1990; Arellano 1992, 2002; Deloya 1992; Capistrán 1992; Estrada et al. 1993; Deloya \& Morón 1994; García-Real 1995; Halffter et al. 1995. The most recent and relevant publications on Canthon in Mexico are Rivera-Cervantes \& Halffter (1999) and Halffter $(1961,2003)$. Solis \& Kohlmann (2002) review Canthon for Costa Rica, as do Howden \& Young (1981) for Panama. In Colombia there are several local revisions (Amézquita et al.1999, Escobar 2000b, Escobar \& Chacón de Ulloa 2000, Neita et al. 2003, Pulido et al. 2003). The catalogue prepared by Medina et al. (2001) list the species for Colombia. Information about the geographic distribution of Canthonini in America is given in Bates (1886-1890), Blackwelder (1944), Vulcano \& Pereira (1964), Halffter \& Martínez (1966, $1977)$, as well as in the previously cited articles.

\section{RESULTS}

\section{Geomorphological cladogram}

The $50 \%$ majority consensus tree of four equally parsimonious trees is shown in Figure 2. The cladogram has 43 steps, a consistency index $(\mathrm{Cl})$ of 0.60 and a retention index of 0.56. The Colombia and Palo Verde (Costa Rica) sites are sister groups and 
Padilla-Gil \& Halffter: Biogeography of Canthonini in Mesoamerica and Colombia

these two, in turn are sister group to Chamela (Mexico). Los Tuxtlas (Mexico) represents the first clade branching out, being the sister group to the other sites included in the analysis.

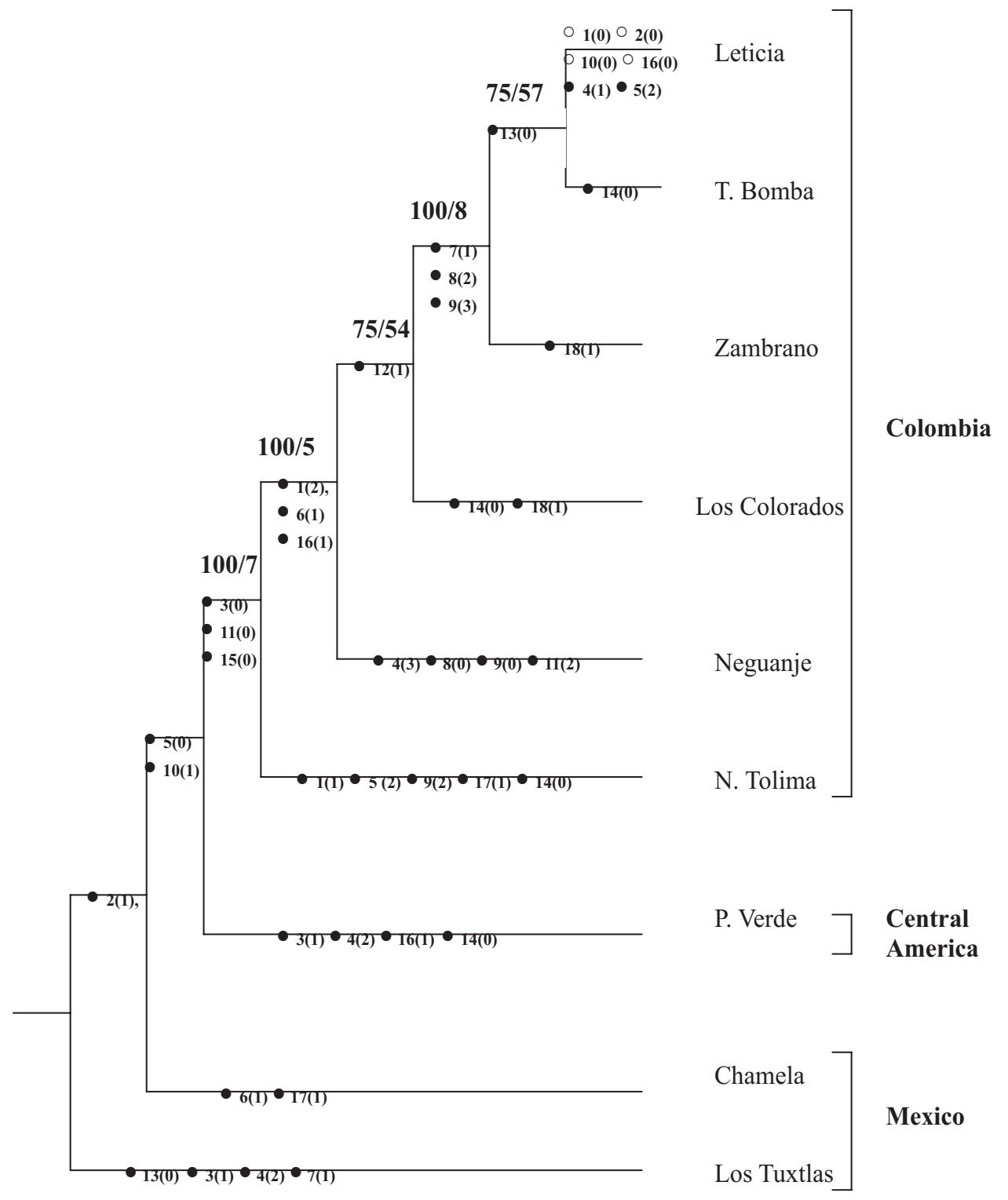

Figure 2

Cladogram of geological areas. The numbers above the nodes indicate $50 \%$ majority consensus tree frequency / Jackknife frequency with $20 \%$ deletion, 500 replicas. In each clade the appearance of derived $=\cdot$ and reversed $=\circ$ characters is indicated.

84 
There are two well supported clades, the first includes Leticia, Tierra Bomba and Zambrano which have both the era and geological period in common: Quaternary: Pleistocene, Holocene. They are also free of tectonic faults. The second well supported clade grouped all the DTF of Colombia and Leticia. All of the sites in Colombia (except Neguanje) have sedimentary rock, though it originates from different processes. In Leticia, the rock results from dendritic accumulations, terraces and alluvial deposits from the margins of the Amazon River. At Tierra Bomba, it originates in marine deposits. In Zambrano, it results from the fluvial-deltaic action of the Magdalena River, at Los Colorados it comes from rocks corresponding to carbonate facies and in the Upper Magdalena River Valley, it is comprised of carbonacious and clay sediments that are both sandy and conglomerate. The soils of the sites are highly developed and have low concentrations of organic material.

Palo Verde and the majority of the sites in Colombia (except Leticia) are characterized by high magnetism and are located on the Caribbean tectonic plate (except Leticia and N. Tolima). Chamela is a sister group to Palo Verde and Colombia, where the soils have optimum concentrations of potassium (except Leticia).

On the other hand the forests studied in the Caribbean Region (except Neguanje) and Leticia (the Amazon) are on sites of very recent geological origin (Quaternary) compared to the DTF of North Tolima, Costa Rica (Palo Verde) and Mexico (Los Tuxtlas and Chamela) which are of Tertiary origin.

\section{The assemblage of the Caribbean Region, Colombia}

The areas where Los Colorados and Neguanje are found, are part of a mosaic of blocks that later came together to form the Caribbean Region. Los Colorados belongs to the San Jacinto Fold Belt which is the result of the interaction between the oceanic crust of the southwestern Caribbean and the continental crust of northern South America. Forces of tension and compression alternated along the platform's margin, especially during the pre-Andina period of orogeny (Middle Eocene) which lifted, folded and shaped this belt. The geomorphological features of the Santa Marta Massif (from which the Neguanje is derived) are the result of its location during the Mesozoic-Tertiary at the intersection of faults on the northeastern corner of South America (González et al. 1988). According to Ujueta (2003) this Massif should be considered a northern extension of the Cordillera Central and its relief is a result of mostly vertical tectonic movement accompanied by moderate horizontal movement.

The tectonic history of San Jacinto, the location of the Sierra Nevada of Santa Marta and the sedimentation of the Plato and San Jorge basins, is correlated in space and time from the Late Miocene to the Pliocene (Caro \& Spratt 2003). The assemblage and the sedimentation of the Caribbean Region of Colombia ended in the Quaternary. It is likely that the climatic and ecological changes were shared by all the sites of the Caribbean Coast of Colombia and so reflect in one way or another the affinities of the biota present in the DTF. The Caribbean Region, together with the north of Venezuela makes up the phytogeographic region of Northern South America (Gentry 1995).

Geomorphological relationships of the study sites and their relationship to the origin of DTF

Three events have exerted a great effect on the evolution of Neotropical flora: the rise of the Andes, the exchange of biota with North America after the formation of the Central American Isthmus and the climatic fluctuations of the Pleistocene (Guariguata \& Katan 2002). This, in addition to the culmination of the majority of orogenic processes that occurred on the continental land of Mexico toward the end of the Pliocene (see Challenger 1998) and the sedimentation of some parts of the mid- and lower Balsas River basin in the Pleistocene. The convergence of 
Padilla-Gil \& Halffter: Biogeography of Canthonini in Mesoamerica and Colombia

the DTF studied can be attributed to the climatic and ecological events of recent geological time, probably since the Pleistocene. This confirms the observations of Gentry (1982) who suggests that the high number of species in the dry tropical area of Mexico is probably the result of an active evolutionary diversification in response to the increase in dry climate regimes during the Pliocene and the Pleistocene. This is in accordance with the higher rate of speciation of the genus Bursera (toward the Pliocene) and its concentration in areas of intermediate and low altitudes of the Pacific Slope of Mexico, and in particular the Balsas River Basin (see Becerra 2005, Rzedowski et al. 2005).

One can think about a general process of south-north expansion since, as Rzedowski (1978) has said, the dry tropical forests of Mexico are characterized by a strong predominance of neotropical elements, and the scarcity or absence of holarctic elements. Although dry forests have their origin in the Pleistocene, it is likely that their current, dry conditions were set during the Middle Holocene in the Caribbean Region of Colombia, as well as on the Pacific coast of Mexico and Costa Rica. During the Middle Holocene, about 5000 to 7000 years B.P. (Steig 1999), the dominant climate system was ITCZ (Intertropical Convergence Zone), given that the ENSO (El Niño-Southern Oscillation) was absent or weak (Fontugne et al. 1999, Cole 2001, Tudhope et al. 2001, Riedinger et al. 2002). Haugh et al. (2001) propose that the driest climatic phase of the Holocene results from the change in the ITCZ to its current position.

\section{Cladogram of the areas of affinity of Canthonini}

The cladogram of the areas of affinity of the Canthonini, with 28 taxa and three subgenera of Canthon (Fig. 3) is the result of the majority consensus of three trees, with 40 steps, and $\mathrm{Cl}$ of 0.77 and an RI of 0.64 . The cladogram groups the Colombian DTF as follows: the first group is comprised of the forests of Tierra Bomba, Zambrano and Neguanje (Caribbean Region); the second is North Tolima alone, and the third group is comprised of Los Colorados, also of the Caribbean Region. In the first group the subgenus Glaphyrocanthon is not represented by a single species; in the other two groups this subgenus is represented by Canthon (GI.) subhyalinus.

The Canthonini of the dry tropical forest of Chamela are more closely related to those of the forests of Colombia. Those of Palo Verde show an affinity to both those of Chamela and those of Colombia. The canthonines of the two tropical rain forests are totally different from each other and do not share any species.

There are three species that characterize the relationships between the dry forests of Colombia: Canthon juvencus, C. cyanellus sallei and C. lituratus (except in Los Colorados). The Amazon (Leticia) only shares $C$. aequinoctialis with the dry forests of North Tolima and Los Colorados Caribbean Region, Colombia).

Chamela has the most exclusive species (Canthon corporali, C. humectus and C. pacificus), and is followed by Palo Verde (Costa Rica): Canthon deyrollei and C. meridionalis, and North Tolima (Colombia) with $C$. acutus.

Eighty-six percent of the species included in the analysis belong to the genus Canthon. To explain these results and explore why such species are found in the forests studied, their distribution patterns are analyzed below (see Table 4 and Appendix 1).

\section{Analysis of the distribution of Canthonini in the dry forests studied}

The cladogram of the species of Canthon for North America (including Mexico) proposed by Kohlmann \& Halffter (1990) shows the spread of this genus from South America in two big expansion events: the first towards the Miocene and the second towards the Plio-Pleistocene 
and continuing to the Recent (see also Halffter 1964, 1976). The phyletic lines that correspond to the first expansion were not influenced by the events that affected the integration and distribution of the dry forests which came afterwards. Their presence in these forests (Chamela) is a result of later colonization. In contrast, the species of the second expansion exhibit a correspondence to the historical and biogeographical conditions that influenced the distribution of DTF: orography that was broadly similar to the current situation, the reestablishment of the connection and exchange of biota between South and North America, and an expansion of the dry conditions in the Holocene.

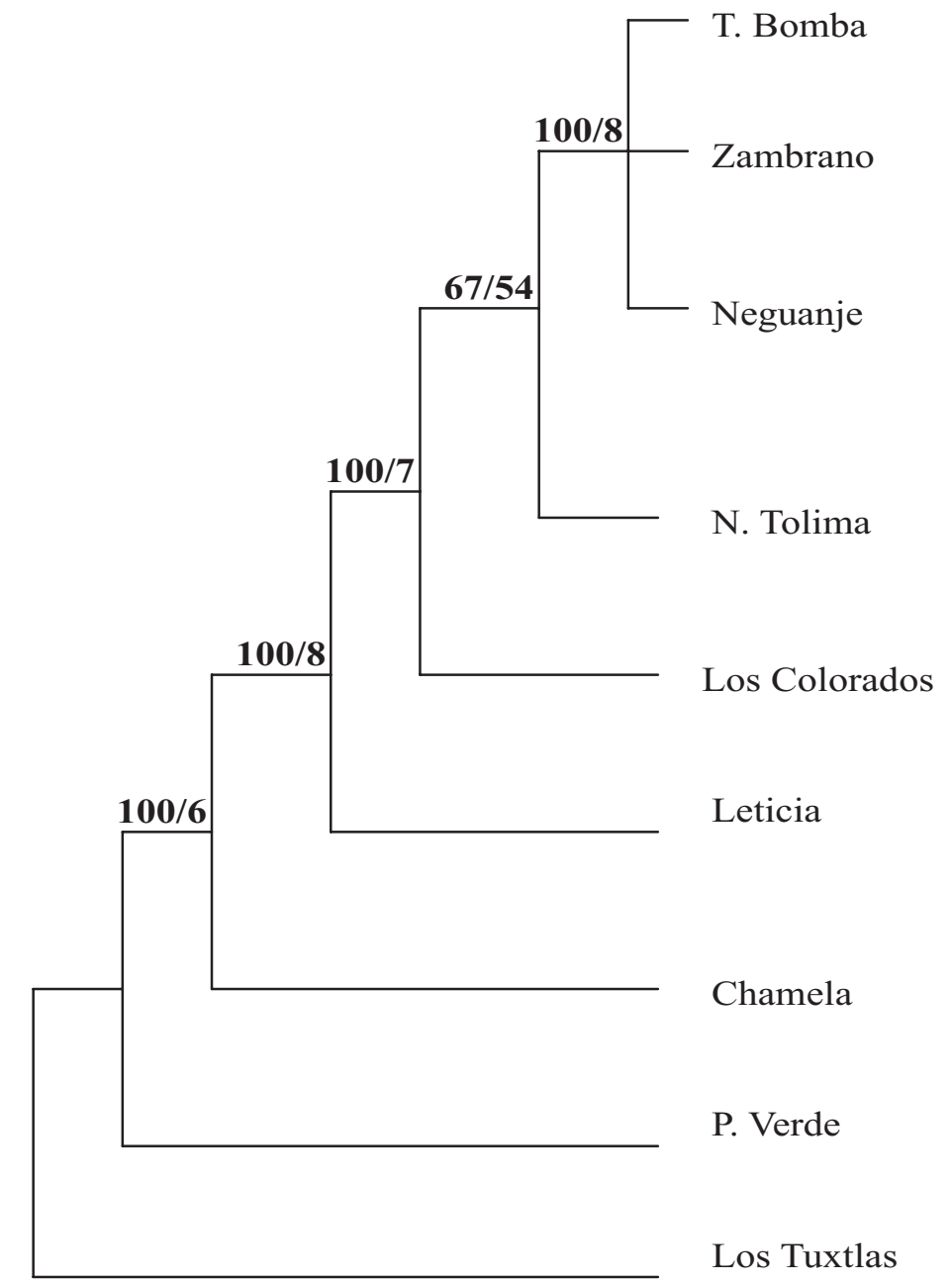

Figure 3

Cladogram of the areas of affinity of Canthonini. The numbers above the nodes indicate $50 \%$ majority consensus tree frequency / Jackknife frequency with $20 \%$ deletion, 500 replicas. 
Padilla-Gil \& Halffter: Biogeography of Canthonini in Mesoamerica and Colombia

In order to explain the presence of Canthonini species in the enclaves of DTF we have studied both the distribution patterns proposed by Halffter (see Halffter 1964, 1976; Kohlmann \& Halffter 1990) and the phyletic lines proposed for taxa of the genus Canthon according to the taxonomic affinities recognized by Halffter \& Martínez (1977), and propose a pattern of speciation in situ.

\section{Pattern 1}

This pattern is observed for species belonging to the phyletic lines that expanded through Mexico, most likely before the Miocene (the High Plains Distribution Pattern of Halffter). These were the earliest species of Neotropical affinity to penetrate the Mexican Transition Zone (MTZ) (Halffter 1976, 1978). Canthon (C.) humectus belongs to this pattern, and represents a phyletically isolated line within the subgenus Canthon according to Halffter \& Martínez (1977). Of the eight subspecies (Halffter \& Halffter 2003) distributed throughout the High Plains of Mexico, Oaxaca, Chiapas and Guatemala, only C. humectus riverai Halffter y Halffter is found in Chamela, a new record not indicated by Andresen (2005); perhaps because it is outside of the area she studied. This species occurs at the lowest altitude for both the species and Canthonini found on the High Plains. It was previously collected in the lower part of the Manantlán Mountain Range (Jalisco) in DTF at altitudes from 700 to $1000 \mathrm{~m}$. Its presence in Chamela can be considered a result of secondary expansion. In a study of the entire Scarabaeoidea superfamily in Chamela, Morón et al. (1988) found some species with the ancient MTZ dispersal patterns, though the majority have the Neotropical Pattern that developed from the Pliocene onwards (see below).

\section{Pattern 2}

These species participated in the expansion that probably began in the Pliocene with the reestablishment of the Panamanian connection, and have different degrees of northwards expansion in North and Central America, to the United States of America (and thus together result in the Typical Neotropical Distribution Pattern of Halffter). The affinities of these species with the South American fauna are much better defined than is the case for Pattern 1 (see affinities under each species). The penetration of these species into the MTZ (Pliocene onwards) could have occurred in distinct stages, depending on the species' antiquity. The most ancient species have undergone processes of subspeciation in the MTZ. We will examine the distribution of these species, from the oldest (and with the widest distribution) to the most recent.

a) Species with a wide distribution that reaches the United States of America.

Canthon (Canthon) indigaceus LeConte ranges from Panama to Texas and Arizona in the United States. In Mexico it is found in tropical landscapes on the Gulf slope, the Pacific slope and the Yucatan Peninsula. It is comprised of three subspecies that are found under different ecological conditions: Canthon i. chiapas in TRF; C. i. chevrolati in places with greater insolation, with less or no woody vegetation; and C. i. indigaceus in DTF or more xerophyllous vegetation. In Chamela we found C. $i$. indigaceus; in Guanacaste, C. i. chevrolati; and in the TRF of Los Tuxtlas, C. $i$. chiapas. Overall, $C$. $i$. indigaceus is a good example of a species exhibiting the Typical Neotropical Pattern with a wide distribution in the MTZ. As in the previous case (Canthon humectus), this species constitutes a phyletic line within the subgenus Canthon (Halffter \& Martínez 1977) that has only one species.

Canthon (C.) cyanellus LeConte has a similar geographic history and distribution, although the latter is broader. It is found from Peru and Brazil to the southern United States and under a wide variety of ecological conditions though it is usually associated with tropical forests or 
treed sites along an altitudinal range from sea level to $2600 \mathrm{~m}$. This species is found at all the DTF sites we studied and in Los Tuxtlas, but not in Leticia.

In Mexico it is found all along the Pacific coast, from Chiapas to Jalisco and on the Atlantic slope it is found on the Yucatan Peninsula and along the Gulf Coast of Mexico up to Tamaulipas and Nuevo León. In the interior of Mexico it is found in the states of Puebla, Morelos, Hidalgo and San Luis Potosí. In Central America, it is found on both the Pacific and the Atlantic slopes; in northern Panama it is found near the Caribbean Sea (Bocas del Toro) and to the south on the border with Colombia in the Darien region on the Pacific coast. In Colombia, according to our findings this species is found throughout the Caribbean Region and the high valley of the Magdalena River, as well as in the Department of Meta (Amézquita et al. 1999, Medina et al. 2001). In Venezuela this species occurs in Táriba, San Cristóbal, as well as in Arima, Trinidad and in Uaupés, Brazil (the Amazon) according to the records of Solís \& Kohlmann (2002). Canthon cyanellus belongs to a phyletic line (the bispinus line) with many species in South America (Halffter \& Martínez 1977).

Malagoniella (Malagoniella) astyanax (Harold). The genus Malagoniella is distributed throughout the Neotropical region, except in Chile and the Antilles. It is richest in species in Argentina, Uruguay, Paraguay and southern Brasil (Halffter \& Martínez 1966). The subgenus Malagoniella has a similar distribution. It includes the only taxon found in the north, M. (M.) astyanax yucateca (Harold), that is found in Central America, Neotropical areas of Mexico and at a point on the border of the United States of America. The other subspecies that make up $M$. astyanax are South American. Citations for Colombia possibly refer to M. (M.) astyanax columbica (Harold), a subspecies for which the distribution is limited to Colombia (Halffter \& Martínez 1966), where it is found in the DTF of Zambrano and North Tolima, as well as in the Departments of Chocó and Magdalena (Medina et al. 2001). This species appears to have a preference for DTF and has not been recorded in Leticia (the Amazon).

Malagoniella (M.) astyanax yucateca (Harold) has a very wide distribution in Mexico and Central America, but has been found at isolated points that are often separated by great distances. In this case, it is difficult to attribute this to capture inefficiency (at least for many of the places where it has not been found), given that this is a large and very striking species. It has been collected in Brownsville, Texas, on the border with Mexico, and also at Tamazunchale (San Luis Potosí), Quintana Roo, Escárcega (Campeche), Puerto Ángel (Oaxaca), Cacahoatan, Tapachula and Rosario Izapa (Chiapas), Yucatan (Bates 1886-1890; Halffter \& Martínez 1966; SNIB-CONABIO database), Guatemala, in the west of Nicaragua and Costa Rica. The Chiapas and Central American sites are on the Pacific slope. In Costa Rica it is restricted to the Guanacaste region, to the northwest of the Pacific coast, over an altitudinal range of 10 to 400 $\mathrm{m}$. In the present study, it is recorded for Palo Verde. Except for the capture in Brownsville (Texas), the rest were captured in tropical forest. $M$. astyanax yucateca appears to be most often associated with seasonal forests (i.e. those that have a dry season). It has not been found in TRF (Los Tuxtlas, Veracruz or Selva Lacandona, Chiapas) within its distribution perimeter.

The distribution of $M$. astyanax appears to reflect an ancient expansion from South America, one that is currently quite fragmented.

Pseudocanthon perplexus (LeConte). The genus Pseudocanthon Bates is comprised of eight species, and two of these are found in Mexico. Of the Mexican species, one is found in 
Padilla-Gil \& Halffter: Biogeography of Canthonini in Mesoamerica and Colombia

the Antilles where there are also five endemic species. The other species is South American. Pseudocanthon perplexus is found in Mexico in both TRF and DTF. It is captured sporadically in sites that are distant from each other. Its distribution extends from the United States of America down to South America. It was found in Chamela and Palo Verde of the DTF we studied.

In Mexico it is distributed along the coast of the Gulf of Mexico up to the eastern United States, and on the Pacific coast to Sonora. In Costa Rica, it has been recorded in Guanacaste Province and in Alajuela on the Cordillera Central, over an altitudinal range of 10 to $540 \mathrm{~m}$ (INBio database). In Panama, it has been found in Balboa in the Canal Zone (Pacific coast).

b) Species with limited penetration into Mexico.

Canthon (C.) morsei Howden is distributed from Ecuador to the warm areas of Mexico, where it extends along the Pacific slope from Chiapas (Halffter et al. 1992) to Jalisco (García-Real 1995). Along the Atlantic slope it ranges northwards up to Tamaulipas. In Costa Rica it is found in the north on the Pacific coast (Solis \& Kohlmann 2002). In Colombia, it is found in the Upper Magdalena River Valley (Tolima). This species is associated with DTF and TRF. In the DTF studied, it was recorded in Palo Verde and in Colombia only in North Tolima. In Mexico, it was not found in the DTF of Chamela, although it is has been recorded in deciduous and semideciduous tropical forests in the state of Jalisco relatively close to Chamela.

According to Halffter \& Martínez (1977) C. morsei belongs to a phyletic line of the subgenus Canthon that includes other South American species.

Canthon (Glaphyrocanthon) subhyalinus Harold is distributed from Bolivia to Mexico and is associated with TRF, especially those sites with monkeys (Halffter 1991, Estrada et al, 1993, Rivera-Cervantes \& Halffter, 1999). This species was not found in the DTF of Chamela or Costa Rica. In Colombia it is associated with DTF in Tolima and in Los Colorados (Bolívar); other records for Colombia include the Departments of Antioquia and Cundinamarca (Medina et al. 2001). In Panama, Howden \& Young (1981) have recorded it for Darien, Santa Fe, and on the Pacific coast and in the Caribbean on Barro Colorado and in the Canal Zone. In Costa Rica it is found in the foothills of premontane wet forest. In Mexico it is only found in the south in the states of Chiapas, Quintana Roo and Veracruz. Canthon subhyalinus is a beetle associated with TRF (Rivera-Cervantes \& Halffter 1999), and so it is probable that the neighbouring vegetation between TRF and DTF facilitates the dispersal of this species toward DTF. This explains the presence of $C$. subhyalinus in Los Colorados, where the DTF includes a patch of TRF, a lone remnant in the Caribbean Region of Colombia (Gentry 1995). It is also found in the DTF of North Tolima, which is between two mountain ranges and in the foothills of the mountain where wet montane forest predominates.

The northern distribution limit for $C$. subhyalinus coincides with that of the howler monkey, Alouatta palliata. It is probable that the dispersal of these species coincide from South America up to Los Tuxtlas. This is supported by field observations of the arboreal behavior of these beetles and their attraction to the dung of these monkeys (Howden \& Young 1981, Halffter 1991, Estrada et al. 1993, Rivera-Cervantes \& Halffter 1999). There is additional support in the origin of these monkeys, Late Miocene to the Pliocene, and their dispersal during the Pleistocene (Cortés-Ortiz et al. 2003), as well as the biogeographic pattern proposed in this study for $C$. subhyalinus.

Canthon (GI.) euryscelis Bates belongs to the same group of species of the subgenus Glaphyrocanthon as C. (GI.) subhyalinus (see Rivera-Cervantes \& Halffter 1999). It is 
distributed in TRF from Mexico to Panama. In the DTF we studied, it was collected at Palo Verde (Guanacaste). Solis \& Kohlmann (2002) indicate that it has a broad tolerance of climate, and is found from sites with marked seasonality (altitude $<800 \mathrm{~m}$ in the Province of Guanacaste) to very humid ones. In Mexico it has been recorded in the TRF of Los Tuxtlas.

Agamopus lampros Bates belongs to a genus (currently under revision by Fernando Vaz de Mello) with four South American species, of which A. lampros extends to Central America and the tropical areas of Mexico. We recorded this species in the DTF of Chamela, Palo Verde (Guanacaste) and Los Colorados (Colombia).

c) The species mentioned below belong to South American phyletic lines whose northern geographic distribution only extends to Central America.

Canthon (Canthon) mutabilis Harold, within the subgenus Canthon, belongs to the bispinus line that, as mentioned in the section on C. cyanellus, is comprised of many South American species. Its distribution extends from Argentina to Costa Rica. It was found in Palo Verde (Guanacaste) and in North Tolima (Colombia). Solis \& Kohlmann (2002) indicate that in Costa Rica it is found from sites that are very humid to those with marked seasonality and a dry season as long as six months. In Colombia, Medina et al. (2001) have recorded it for the Departments of Bolivar and Meta, associated with dry conditions. Canthon juvencus, $C$. mutabilis and C. meridionalis are abundant in the driest forests of some of the smallest islands in Lake Gatun and Gamboa (Caribbean region) near the continent (Gill 1991).

Canthon (C.) lituratus (Germar) is also widely dispersed from Argentina to Costa Rica. It belongs to a phyletic line within the subgenus Canthon that includes another South American species (Halffter \& Martínez 1977). In Colombia it is found in Tolima and in the Caribbean Region in all the DTF studied, except for Los Colorados. In Colombia, Medina et al. (2001) have recorded it for the Departament of Valle. In Costa Rica it is only found to the southwest of the Pacific coast, in the savannahs bordering the Térraba River (Solis \& Kohlmann 2002). Its distribution extends southwards from the Pacific, and it has also been recorded for the provinces of Chiriqui and Cocle in Panama at altitudes above $800 \mathrm{~m}$ (Howden \& Young 1981).

Canthon (C.) juvencus Harold is found from Brazil to Costa Rica. In Colombia it is found in the DTF of the Caribbean Region and in the Upper Magdalena River Valley (Tolima) as well as in other Departments in Colombia: Guainia, Guaviare, and Meta (Amézquita et al. 1999, Medina et al. 2001, Escobar 2000b). In Costa Rica it is restricted to the southern Pacific in TRF located below $500 \mathrm{~m}$ (Solis \& Kohlmann 2002). It is found in Panama in the pronvinces of Panama, Colon and the Canal Zone (Howden \& Young 1981).

Canthon septemmaculatus (Latreille) has a broad distribution range from Argentina to Costa Rica. In the DTF studied, it was only recorded in Zambrano Caribbean Region, Colombia. Medina et al. (2001) have recorded it for the Colombian Departments of Bolivar, Chocó, Meta, Caquetá and Nariño. In Panama it has been recorded in the provinces of Los Santos, Coclé, Panamá and the Canal Zone. In Costa Rica it is only found to the southwest of the Pacific coast, in the savannas surrounding the Térraba River (Solis \& Kohlmann 2002).

Canthon (C.) aequinoctialis Harold occurs from Brazil to Belize. According to Halffter \& Martínez (1977) it belongs to a South American phyletic line of the genus Canthon. In Colombia it is 
Padilla-Gil \& Halffter: Biogeography of Canthonini in Mesoamerica and Colombia

found in both the DTF of the Upper Magdalena River Valley (Tolima), in Los Colorados (Caribbean Region) and in the TRF of Leticia (the Amazon). It has also been found in the Departments of Antioquia, Caquetá, Choco, Guainia, Guaviare, Meta, Nariño, Valle, and Cauca (Escobar 2000 a, Medina et al. 2001, Neita et al. 2003, Pulido et al. 2003). In Panama it is found to the north, on the Pacific coast and in the Canal Zone on the Caribbean. In Costa Rica it is spread out along the Caribbean and to the north of the country, but it was not recorded in Palo Verde (Guanacaste). On the Pacific coast, it has been cited for two sectors: to the south on the Osa Peninsula and in the basin of the River Tárcoles, with a marked preference for TRF (Solis \& Kohlmann 2002).

\section{Pattern 3}

These taxa likely reflect the processes of speciation in situ in the DTF of Mexico, Costa Rica and Colombia.

Glaphyrocanthon, a subgenus of Canthon with many South American species, has two phyletic lines in Mexico with a clear origin in the north of South America. We have already referred to one of these lines, that of $C$. (GI.) subhyalinus. The second line is comprised of an isolated species with South American affinities. In addition there is the viridis group with strong speciation in Mexico and which clearly belongs to the subgenus Glaphyrocanthon although it has no evident relationship to South American species.

The viridis group is comprised of 15 species, of which only C. (Gl.) meridionalis Martínez, Halffter y Halffter has a distribution that expands towards Central America, opposite to the dominant direction for the distribution of the Canthonini studied. Several of the species of this group are associated with TRF, many others are found in DTF.

Canthon (Glaphyrocanthon) pacificus Rivera y Halffter and C. (GI.) corporali Balthasar belong to this group and both form part of a set of species that are distributed in Mexico along the Pacific slope, from the state of Nayarit to the state of Oaxaca. Canthon (Gl.) corporali is widely distributed in association with DTF, including the Balsas River Basin and the coast of the Pacific on both sides of its outlet. Canthon (GI.) pacificus is found in dry deciduous and semideciduous forests of the Pacific coast, from the state of Jalisco to the state of Oaxaca.

From the same viridis group in Guanacaste the lone species C. (Gl.) meridionalis Martínez, Halffter y Halffter is found and extends to Central America: Guatemala, El Salvador, Nicaragua, and Costa Rica (Solis \& Kohlmann 2002). In Costa Rica it has a wide distribution, on both the Pacific and the Atlantic sides (Solis \& Kohlmann 2002).

Canthon (C.) deyrollei Harold has a geographic distribution from Guatemala to Costa Rica. It is the only species in its phyletic line (Halffter \& Martínez 1977). In Costa Rica it is restricted to the area with the greatest climatic seasonality, i.e. land below $600 \mathrm{~m}$ in the province of Guanacaste, in the northwest of Costa Rica (Solis \& Kohlmann 2002).

Canthon (GI.) acutus Harold was collected in North Tolima. It has also been found in other Departments in Colombia: Bolívar, Guainia and Meta at elevations of 300 m (Medina et al. 2001).

\section{DISCUSSION}

1) The geological (Fig. 2) and Canthonini species composition (Fig. 3) cladograms only coincide in their general features. The dry tropical forests from Mexico to Colombia arose during a relatively recent geological stage. Hence, historical geological events 
prior to the Pliocene do not appear to have affected the distribution of this vegetation type. Its distribution is determined by a combination of temperature and rainfall conditions, particularly by a prolonged and marked dry season (see Rzedowski 1978).

2) The flora of dry tropical forests is almost exclusively comprised of species with Neotropical affinities (Rzedowski 1978). The Canthonini fauna has the same affinities. As shown by Trejo (2005), there is a high degree of plant species exchange between different dry tropical forest sites. It is not surprising that the same phenomenon occurs in the Canthonini.

The cladograms of the dry tropical forests and the Canthonini exhibit the same affinities found by Gentry (1995) for flora; i.e. a strong similarity between the dry forests of northern Colombia and Venezuela with that of Chamela, with 15 shared genera, while Chamela and Guanacaste (Costa Rica) only share six genera.

3) The Canthonini species found in the dry tropical forests studied show a clear gradient of affinity associated with the different degrees of expansion of the Canthonini from South America. In spite of the great distance and the ecological barriers that exist between Colombia and Chamela, the affinities are marked and appear to indicate a certain degree of continuity among the dry forests studied.

There is little doubt that the expansion of the distribution area of South American Canthonini, and that of many other Scarabaeinae with the same biogeographical history was greatly facilitated by the presence of mammalian megafauna that has since disappeared (see Janzen \& Martin 1982). Nevertheless, there are differences among the enclaves of dry tropical forest. In Chamela, the only pre-Pliocene expansion species was collected (Canthon humectus), along with several species of ancient expansion within the Neotropical Pattern, and several species whose distribution in Mexico is more recent, including two belonging to a group (Canthon (Glaphyrocanthon) viridis group) which speciated in Mexico. Palo Verde has a mix of Plio-Pleistocene and recent expansion species. In Colombia, species with a South American distribution dominate, although it shares species with Palo Verde and Chamela.

The biogeographical hypothesis proposed in the Introduction about the origin of Canthonini and their northwards expansion at different times and with different degrees of penetration is supported. The relationships between distinct phyletic lines and even species, with South American fauna clearly demonstrate these biogeographical phenomena.

4) Several of the species found in Colombia, but not in Palo Verde or Chamela, have the northern limit of their distribution in the Térraba River basin in the extreme south of Costa Rica on the Pacific coast. This is the case for $C$. lituratus, $C$. juvencus, and $C$. septemmaculatus (see Solis \& Kohlmann 2002). As these species do not reach Palo Verde the differences of this site with those of Colombia are accentuated. This northern limit in the distribution of South American species to the extreme south of Costa Rica is interesting. The lowlands of Nicaragua to the north of Lake Nicaragua were proposed by Halffter (1976) as the southern limit of the Mexican Transition Zone. The present study shows the South American affinity of the Canthonini of Costa Rica for dry tropical forest 
Padilla-Gil \& Halffter: Biogeography of Canthonini in Mesoamerica and Colombia

(they share $40 \%$ of the species with the DTF of North Tolima), and this seems to apply in general to those species found in other types of vegetation (see Solis \& Kohlmann 2002).

5) A good number of the species found in the sites we studied are characteristic of dry tropical forest, and even exclusive to this vegetation type. However, some species are shared with tropical rain forest. The proportion of shared species is much lower in Chamela, moderate in Palo Verde and greatest in the sites of Colombia. The latter is also reflected in the greater affinity of the Canthonini of Colombian DTF with those of Leticia (TRF), than with those of the DTF of Chamela (Fig. 3). Palo Verde shares $30 \%$ of its species with Los Tuxtlas, a forest where the DTF and the TRF species of Mesoamerica meet.

6) As regards in situ speciation, the most notable example is that of the viridis group, which has no direct relationship with the South American fauna of Canthon (Glaphyrocanthon). This group underwent much diversification in Mexico that appears to be recent and influenced by the process of drying out during the Holocene (many of its species are adapted to dry forest).

7) The enclaves of dry tropical forest in Colombia, in both the Caribbean Region and the Upper Magdalena Valley, are close to tropical rain forest. In the first case, Neguanje is part of the Province of the Sierra Nevada of Santa Marta where the vegetation change with increasing altitude and in Los Colorados there is still a remanent of rain forest. The Upper Magdalena River Valley is surrounded by rain forest on the skirts of the Cordillera Central and the Cordillera Oriental, and to the north by the Middle Magdalena Valley. This allows them to share species with adjacent ecosystems.

8) The Canthonini fauna of the tropical rain forests (Los Tuxtlas and Leticia) that were used as the outgroup, is very different between these two rain forests and also different from the fauna of the dry tropical forests. Considering all Scarabaeoidea, the similarity in species between Chamela and Los Tuxtlas is only 13 (Sørensen's QS index), while between Chamela and other dry tropical forest in Mexico the value is 41 (Morón et al. 1988).

9) The quality of the species list is the main limitation of the biogeographical analysis presented here. We have gathered all of the published information as well as that recorded in the databases of CONABIO and INBIO. Even so, these collections cannot be considered exhaustive, especially for Colombia.

10) The predominance of roller species (Canthonini) in dry tropical forest is well defined. On average $33.45 \%$ of the Scarabaeinae species found are Canthonini, a value that rises to $35.45 \%$ if we exclude Neguanje as the least representative site. In contrast, in the tropical rain forests studied, on average only $28 \%$ are rollers. The affinity of the rollers for sunny conditions is even greater in sites that are drier and have very open vegetation.

11) There have been several studies of the changes in the abundance of Scarabaeinae species from the dry season to the rainy season in dry tropical forest: Chamela (Andresen 2005), North Tolima (Escobar 1997), Guanacaste, Costa Rica (Janzen 1983) have produced similar results and emphasize the severity of the dry season. Soil humidity and ambient temperature control the activity and life cycle of Scarabaeinae (Halffter 1991, Martínez \& Montes de Oca 1994, Bustos-Gómez \& Lopera-Toro 2003, Andresen 2005). On the other 
hand, the Scarabaeinae of dry tropical forests show a marked tendency for a generalist diet (copro-necrophagous). In Chamela $70 \%$ of Scarabaeinae (Andresen 2005) and in the north of Tolima 71\% (Bustos-Gómez \& Lopera-Toro 2003) have this type of diet.

\section{Closing Remarks}

The biogeographical analysis of areas of dry tropical forest in Mesoamerica and Colombia has provided and integrated geological, geomorphological, climatic and ecological elements that have brought us closer to understanding the origin and relationships of Neotropical dry forests.

The use of an outgroup polarized the cladograms, adding a new dimension to the study by establishing an axis for comparison that stood out in all analyses. The analises carried out, along with previous knowledge of the group allowed for an explanation of the spatio-temporal dynamics exhibited by the Canthonini in dry tropical forests.

Dry tropical forest represents a setting where the processes of vicariance and dispersal occur. This study reveals Canthonini's routes of dispersal via the dry forests while the speciation processes of some Canthon, appearing to be synchronous with the establishment of the dry forests of Mesoamerica and Colombia, also indicate the affinities of Canthonini to dry tropical forest, very similar to that of the flora of said ecosystem.

Biogeographical and ecological elements were brought together and these allowed us to explain both their presence in and the preference of some Canthonini for dry forest, and/or their exclusive distribution in some dry forests of Colombia and their absence from those of Mesoamerica, as was the case for $C$. (GI.) subhyalinus, so clearly demonstrated by the PAE.

\section{ACKNOWLEDGEMENTS}

The first author is grateful to A. Espinosa de los Monteros and J. J. Morrone for their comments on the manuscript; to F. Escobar, M. Zunino, A. Solís, F. Vaz de Mello and A. Díaz, for providing bibliographic material; to $\mathrm{C}$. Álvarez for providing access to the SNIB-CONABIO data base projects E7, K5, P134, G19, H125 in Mexico City and the data base of the National Biodiversity Institute in Costa Rica, Atta: Information System on Costa Rican Biodiversity (http:/ /www.inbio.ac.cr/atta/index.htm). Thanks also to the Universidad de Nariño, Pasto (Colombia: Nariño) for the award of a Commission to Study.

We thank two anonymous reviewers for their very useful comments. We are also are grateful to B. Delfosse for translating the manuscript into English. This study represents part of the project "Analysis of the relationships between alpha, beta and gamma diversity on different spatial scales: the historical and ecological processes involved", Stage V (CONABIOMexico).

\section{LITERATURE CITED}

Alfaro, E. A., A. Alvarado, \& A. Chavarri. 2001. Cambios edáficos asociados a tres etapas sucesionales de bosque tropical seco en Guanacaste, Costa Rica. Agronomía Costarricense, 21 (1):7-20. 
Padilla-Gil \& Halffter: Biogeography of Canthonini in Mesoamerica and Colombia

Alvarado, G., R. Barquero, I. Boschini, S. Chiesa, \& M. Carr. 1986. Relación entre geotectónica y vulcanismo en Costa Rica. Revista CIAF, 11 (1-3):246-264.

Andresen, E. 2005. Effects of season and vegetation type on community organization of dung beetles in a tropical dry forest. Biotropica, 37 (2):291-300.

Amézquita, S J., A. Forsyth, A. Lopera, \& A. Camacho. 1999. Comparación de la composición y riqueza de especies de escarabajos coprófagos (Coleoptera: Scarabaeidae) en remanentes de bosque de la Orinoquia Colombiana. Acta Zool. Mex. (n. s.), 76:113-126.

Arellano, L. 1992. Distribución y abundancia de Scarabaeidae y Silphidae (Insecta: Coleoptera) en un transecto altitudinal en el estado de Veracruz. Bachelor of Science Thesis. Facultad de Ciencias, Universidad Nacional Autónoma de México.

2002. Evaluación de la diversidad alfa, beta y gamma de Scarabaeoidea y Silphidae (Insecta: Coleoptera) en la región Cofre de Perote, Veracruz, México. Master of Science Thesis. Facultad de Ciencias, Universidad Nacional Autónoma de México.

Aucott, J. W. 1983. The application of moving average analysis to seismic data and its interpretation related to the structure of Ecuador and Colombia. Memorias 10a Conferencia Geológica del Caribe. Cartagena de Indias. INGEOMINAS. Bogotá, Colombia.

Bandy, W., V. Kostoglodov, A. Hurtado-Díaz, \& M. Mena. 1999. Structure of the southern Jalisco subduction zone, Mexico, as inferred from gravity and seismicity. Geofísica Internacional, 38 (3):127-136.

Barrera, A. 1969. Coleoptera en la Colección Nacional. Acta Zool. Mex., 9 (6):1-90.

Bates, H. W. 1886-1890. Pectinicornia and Lamellicornia. Biol. Cent. Amer., Zool. Insecta. Coleoptera. Vol. 2. P art. 2. Taylor and Francis, London.

Becerra, J. X. 2005. Timing the origin and expansion of the Mexican tropical dry forest. PNAS, 102 (31):10919-10923.

Blackwelder, R. 1944. Checklist of the Coleopterous insects of Mexico, Central America, the West Indies and South America. U. S. Natl. Mus. Bull., 185:196-220.

Bullock S. H. 1988. Rasgos del ambiente físico y biológico de Chamela, Jalisco, México. Folia Entomol. Mex., 77:5-17

Bustos-Gómez L. F., \& A. Lopera-Toro. 2003. Preferencia por cebo de los escarabajos coprófagos (Coleoptera: Scarabaeidae: Scarabaeinae) de un remanente de bosque seco tropical al norte del Tolima (Colombia). Pp. 59-65. In: G. Onore, P. Reyes-Castillo, \& M. Zunino (eds.), Escarabeidos de Latinoamérica: Estado del conocimiento. Monografías Tercer Milenio, SEA, Vol. 3, Zaragoza, Spain.

Campo-Alves, J. 2003. Disponibilidad y flujos de nutrimentos en una toposecuencia con bosque tropical seco en México. Agrociencia, 37:211-219.

Capistrán, H. F. 1992. Los Coleopteros del Parque de Flora y Fauna Silvestre Tropical Pipiapan, Catemaco, Veracruz, México. Bachelor of Science Thesis. Facultad de Biología, Universidad Veracruzana, Xalapa, Veracruz.

Caro, M., \& D. Spratt. 2003. Tectonic Evolution of the San Jacinto Fold Belt, NW Colombia. CSEG Recorder 36-43.

Challenger, A. (1998) Utilización y conservación de los ecosistemas terrestres de México, pasado, presente y futuro. CONABIO. México.

Chiesa, S., G. E. Alvarado, M. Pecchio, M. Corella, \& A. Zanchi. 1994. Contribution to petrological and stratigraphical understanding of the Cordillera de Guanacaste lava flows, Costa Rica. Rev. Geol. América Central, 17:19-43.

Cole, J. 2001. A slow dance for El Niño. Science, 291:1496-1497.

CONABIO. 1990. Vegetación potencial de Rzedowski. Escala 1: 400 000. México. 
Cortés-Ortiz, L., E. Birmingham, C. Rico, E. Rodríguez-Luna, I. Sampaio, \& M. Ruiz-García. 2003. Molecular systematics and biogeography of the Neotropical monkey genus, Alouatta. Mol. Phylogenet. Evol., 26:64-81.

Craw, R. 1988. Continuing the synthesis between panbiogeography, phylogenetic systematic and geology as illustrated by empirical studies on the biogeography of New Zeland and the Chatham Islands. Syst. Zool., 37 (3):291-310.

Cuevas, O. J. L., L. L. A. Díaz, \& G. B. Polo. 2003. Mapas generalizados de las anomalías del Caribe Occidental y América Central. V Cuban Geological Congress. Memorias Geomin. La Habana. Cuba.

Delgado, L. L. 1989. Fauna de Coleópteros Lamellicornios de Acahuizotla, Guerrero, México. Bachelor of Science Thesis. Facultad de Ciencias, Universidad Nacional Autónoma de México.

Deloya, C. 1992. Necrophilous Scarabaeidae and Trogidae Beetles of Tropical Deciduous Forest in Tepexco, Puebla, México. Acta Zool. Mex. (n.s.), 52:1-13.

Deloya, C., \& M. A. Morón. 1994. Coleópteros Lamellicornios del Distrito de Jojutla, Morelos, México (Melolonthidae, Scarabaeidae, Trogidae y Passalidae). Listados Faunísticos de México V. Universidad Nacional Autónoma de México. . 1998. Scarabaeoidea (Insecta: Coleoptera) necrófagos de Los Tuxtlas, Veracruz y Puerto Angel, Oaxaca, México. Dugesiana, 5 (2):17-28.

Deloya, C., G. Ruíz-Lizárraga, \& M. A. Morón. 1987. Análisis de la entomofauna necrófila en la región de Jojutla, Morelos, México. Folia Entomol. Mex., 73:157-171.

Díaz, R. A. 1998. Ecología y comportamiento de escarabajos rodadores del estiércol (Scarabaeidae: Scarabaeinae) de selvas y pastizales en Los Tuxtlas, Veracruz. Master of Science Thesis. Ecología y Ciencias Ambientales. Facultad de Ciencias, Universidad Nacional Autónoma de México. . 2003. Efecto de la fragmentación de selvas en poblaciones de Scarabaeidae y Silphidae (Coleoptera) de Los Tuxtlas, México. Doctoral Thesis. Facultad de Ciencias, Universidad de Alicante. Spain.

Escobar, F. 1997. Estudio de la comunidad de coleópteros coprófagos (Scarabaeidae) en un remanente de bosque seco al norte del Tolima, Colombia. Caldasia, 19 (3):419430.

1998. Análisis regional de la comunidad de escarabajos coprófagos (Coleoptera: Scarabaeidae: Scarabaeinae) de los bosques secos de la región Caribe de Colombia. pp. 72-75 In: M. E. Chaves, \& N. Arango (eds.), Informe Nacional sobre el Estado de la Biodiversidad-Colombia. Instituto Alexander von Humboldt, PNUMA, Ministerio del Medio Ambiente. Bogotá, Colombia.

. 2000a. Diversidad y distribución de los escarabajos del estiércol (Coleoptera: Scarabaeidae: Scarabaeinae) de Colombia. Pp. 197-210 In: F. Martín-Piera, J. J. Morrone, \& A. Melic (eds.), Hacia un proyecto CYTED para el inventario y estimación de la diversidad entomológica en Iberoamérica: PrIBES-2000. Monografías Tercer Milenio, SEA, Vol. 1, Zaragoza, Spain.

. 2000b. Diversidad de coleópteros coprófagos (Scarabaeidae: Scarabaeinae) en un mosaico de habitats en la Reserva Natural Nukak, Guaviare, Colombia. Acta Zool. Mex. (n.s.), 79:103-121.

Escobar, F., \& P. Chacón de Ulloa. 2000. Distribución espacial y temporal en un gradiente de sucesión de la fauna de coleópteros coprófagos (Scarabaeinae, Aphodiinae) en un bosque tropical montano, Nariño, Colombia. Rev. Biol. Trop., 48 (4):961-975. 
Padilla-Gil \& Halffter: Biogeography of Canthonini in Mesoamerica and Colombia

Espinal, L. S. 1985. Geografía ecológica del departamento de Antioquia. Rev. Fac. Nac. Agr. Medellín, Colombia, 38 (1):24-39.

Estrada, A., G. Halffter, R. Coates-Estrada, \& D. A. Meritt Jr. 1993. Dung beetles attracted to mammalian herbivore (Alouatta palliata) and omnivore (Nasua narica) dung in the tropical rain forest of Los Tuxtlas, México. J. Trop. Ecol., 9 (1):45-54.

Etter, A. 1993. Diversidad ecosistémica en Colombia hoy. Pp. 43-61 In: S. Cárdenas, \& H. D. Correa (eds.), Nuestra diversidad biológica. Fundación Alejandro Escobar, Colección María Restrepo de Angel, CEREC. Santafé de Bogotá.

Favila, M. E., \& A. Díaz. 1997. Escarabajos coprófagos y necrófagos. Pp. 383-387 In: E. González-Soriano, R. Dirzo, \& R. Vogt (eds.), Historia Natural de los Tuxtlas. Universidad Nacional Autónoma de México.

Ferrari, L., \& J. Rosas-Elguera. 1999. Late Miocene to Quaternary extension at the northern boundary of the Jalisco block, western Mexico: The Tepic-Zocalo rift revised. Pp. 1-23 In: H. Delgado-Granados, G. Aguirre-Díaz, \& J. M. Stock (eds.), Cenozoic Tectonics and Volcanism of Mexico. Geol. Soc. Amer. Special Paper 334.

Ferrari, L., G. Pasquarè, S. Venegas-Salgado, \& F. Romero-Ríos. 1999. Geology of the Western Mexican Volcanic Belt and adjacent Sierra Madre Occidental and Jalisco block. Pp. 65-83 In: H. Delgado-Granados, G. Aguirre-Díaz, \& J. M. Stock (eds.), Cenozoic Tectonics and Volcanism of Mexico. Geol. Soc. Amer. Special Paper 334.

Fontugne, M., P. Usselmann, M. Lavallée, M. Julien, \& C. Hatté. 1999. El Niño variability in the coastal desert of southern Peru during the mid Holocene. Quat. Res., 52:171-179.

Galvis, J., G. A. Huguett, \& T. P. Ruge. 1979. Geología de la Amazonía Colombiana. Boletín Geológico. INGEOMINAS, Bogotá, Colombia, 22 (3):1-153.

García-Real, E. 1995. Abundancia, distribución y estructura de la comunidad de escarabajos coprófagos y necrófagos (Coleoptera: Scarabaeidae) en un gradiente altitudinal de la Sierra de Manantlán, Jalisco-Colima, México. Master of Science Thesis. Colegio de Postgraduados, Montecillo, México.

Gentry, A. H. 1982. Neotropical floristic diversity: phytogeographical connections between Central and South America, Pleistocene climatic fluctuations, or an accident of the Andean orogeny? Ann. Missouri Bot. Gard., 69:557-593.

1995. Diversity and floristic composition of neotropical dry forest. Pp. 146-195 In: S. H. Bullock, H. A. Mooney \& E. Medina (eds.), Seasonally dry tropical forests. Cambridge University Press, Cambridge.

Gill, B. D. 1991. Dung beetles in tropical American forests. Pp. 211-229 In: I. Hanski, \& Y. Cambefort (eds.), Dung beetle ecology. Princeton University Press. Princeton, NJ.

Giunta, G., E. Navarro, L. Beccaluva, S. Bellia, P. Comin-Chiaramonti, G. Dengo, W. Montero, F. Urbani, \& S. Carnemolla. 1996. Geología de las márgenes de la placa del Caribe: generalidades en Guatemala, Costa Rica, La Española y resultados preliminares del análisis de una transversa en la cordillera de la Costa de Venezuela. Rev. Geol. América Central, 19 (20):7-28.

Gómez, L. D. 1982. The origin of the Pteridophyte flora of Central America. Ann. Missouri Bot. Gard., 69:548-556.

González, H., A. Nuñez, \& G. París. 1988. Mapa geológico de Colombia. Escala: 1:1.500.000. INGOMINAS. Bogotá, Colombia.

Graham, A. 2003. In the Beginning: Early Events in the Development of Mesoamerica and the Lowland Maya Area. Pp. 31-44 In: A. Gómez-Pompa, M. F. Allen, S. L. Fedick, J.J. JiménezOsorio (eds.), The Lowland Maya Area three millennia at the human-wildland humanwildland interface. Food Products Press an Imprint of the Haworth Press, Inc. New York. 
Guariguata, M. R., \& G. H. Katan. 2002. El bosque neotropical: pasado y presente (Sección I). Ecología y conservación de bosques neotropicales. Libro Universitario Regional. Cartago, Costa Rica.

Halffter, G. 1961. Monografía de las especies norteamericanas del género Canthon Hoffsg. (Coleoptera, Scarabaeidae) Ciencia, Mex., 20 (9-12):225-320. 1964. La entomofauna mexicana, ideas acerca de su origen y distribución. Folia Entomol. Mex., 6:1-108.

. 1974. Eléments anciens de l'Entomofaune Néotropicale: Ses implications biogeographiques. Quaest. Entomol., 10:223-262. . 1976. Distribución de los insectos en la Zona de Transición Mexicana. Folia Entomol. Mex., 35:1-64 . 1978. Un nuevo patrón de dispersión de la Zona de Transición Mexicana: El Mesoamericano de Montaña. Folia Ent. Mex., 39-40:219-222. 1991. Historical and ecological factors determining the geographical distribution of beetles (Coleoptera: Scarabaeidae: Scarabaeinae). Folia Entomol. Mex., 82:195-238. . 2003. Tribu Scarabaeini. Pp. 211-229 In: M. A. Morón (ed.), Atlas de los escarabajos de México Coleoptera: Lamellicornia, vol 2: Scarabaeidae, Trogidae, Passalidae y Lucanidae. Argania Editio. Barcelona, Spain.

Halffter G, M. E. Favila, \& L. Arellano. 1995. Spatial distribution of three groups of Coleoptera along an altitudinal transect in the Mexican Transition Zone and its biogeographical implications. Elytron, 9:151-185.

Halffter, G., M. E. Favila, \& V. Halffter. 1992. A comparative study of the structure of the scarab guild in Mexican tropical rain forests and derived ecosystems. Folia Entomol. Mex., 84:131-156.

Halffter, G., \& A. Martínez. 1966. Revisión monográfica de los Canthonina americanos (Coleoptera, Scarabaeidae) la Parte. Rev. Soc. Mex. Hist. Nat., 27:89-177. . 1977. Revisión monográfica de los Canthonina americanos. Parte IV. Clave para géneros y subgéneros. Folia Entomol. Mex., 38:29-107.

Halffter, G., \& E. G. Matthews. 1966. The natural history of dung beetles of the subfamily Scarabaeinae (Coleoptera: Scarabaeidae). Folia Entomol. Mex., 12-14:1-312.

Halffter, V., \& G. Halffter. 2003. Nuevas subespecies de Canthon humectus (Say) (Coleoptera: Scarabaeidae: Scarabaeinae). Folia Entomol. Mex., 42 (3):329-340.

Haugh, G., K. Hughen, D. Sigman, L. Peterson, \& U. Röhl. 2001. Southward migration of the Intertropical Convergence Zone through the Holocene. Science, 293:1304-1307.

Henríquez, C., E. Bornemisza, \& F. Bertsch. 1994. Fijación de potasio en vertisoles, inceptisoles, andisoles y ultisoles de Costa Rica. Agronomía Costarricense, 18 (2):133-140.

Hernández-Quintero, J. E. 2003. Magnetic satellite anomalies over Mexico. The Geological Society of America, Cordilleran Section, 99th Annual Meeting (April 1-3 2003). Puerto Vallarta. Jalisco.

Herrera, L. F., G. Sarmiento, F. Romero, P. J. Botero, \& J. Berrio. 2001. Evaluación ambiental de la Depresión Momposina (Colombia) desde el Pleistoceno Tardío a los paisajes actuales. Geología Colombiana, 26:95-121.

Hooghiemstra, H \& T. van der Hammen. 2001. Desarrollo del bosque húmedo neotropical en el Neógeno y Cuaternario: la hipótesis de los refugios. Pp. 129-136 In: J. LlorenteBousquets, \& J.J. Morrone (eds.), Introducción a la biogeografía en Latinoamérica. Teorías, conceptos, métodos y aplicaciones. Facultad de Ciencias. UNAM. 
Padilla-Gil \& Halffter: Biogeography of Canthonini in Mesoamerica and Colombia

Hooghiemstra, H., T. van der Hammen, \& A. Cleef. 2002. Paleoecología de la flora boscosa. Pp. 43-58 In: M. R. Guariguata, \& G. H. Katan (eds.), El bosque neotropical pasado y presente (Sección I) Ecología y conservación de bosques neotropicales. Costa Rica.

Howden, H. F., \& V. Nealis. 1975. Effects of clearing in a tropical rain forest on the composition of the coprophagous scarab beetle fauna (Coleoptera). Biotropica, 7:77-85.

Howden, H. F., \& O. P. Young. 1981. Panamanian Scarabaeinae: taxonomy, distribution and habits (Coleoptera Scarabaeidae). Contrib. Amer. Ent. Inst., 18 (1):1-104.

(IAvH) Instituto Alexander von Humboldt. 1997a. Caracterización ecológica de cuatro remanentes de bosque seco tropical de la región Caribe colombiana. Grupo de Exploraciones Ecológicas Rápidas, IAvH. Villa de Leyva. Colombia. 1997b. Diversidad Biológica. Informe nacional sobre el estado de la biodiversidad Colombia. IAvH, Ministerio del Medio Ambiente, PNUMA. Santafé de Bogotá, Colombia. . 2000. Colombia Megadiversa: cinco años explorando la riqueza de un país biodiverso. Santafé de Bogotá, Colombia.

Jaccard, S., M. Münster, P. O. Baumgartner, C. Baumgartner-Mora, \& P. Denyer. 2001. Barra Honda (Upper Paleocene-lower Eocene) and El Viejo (Campanian-Maastrichtian) carbonate platforms in the tempisque area (Guanacaste, Costa Rica). Rev. Geol. América Central, 24:9-28.

Janzen, D. H. 1983. Seasonal change in abundance of large nocturnal dung beetles (Scarabaeidae) in a Costa Rican deciduous forest and adjacent horse pasture. Oikos, 41:274-283.

Janzen, D. H., \& P. S. Martin. 1982. Neotropical anachronisms: the fruits the Gomphotheres ate. Science, 215:19-27.

Kohlmann, B., \& G. Halffter. 1990. Reconstruction of a specific example of insect invasion waves: the cladistic analysis of Canthon (Coleoptera: Scarabaeidae) and related genera in North America. Quaest. Entomol., 26 (1):1-28.

Kohlmann, B., \& J. Wilkinson. 2003. Fronteras Biogeográficas: Coincidencia entre factores climáticos, topográficos, geológicos e históricos. Pp. 221-226 In: J. J. Morrone, \& J. Llorente-Bousquets (eds.), Una Perspectiva Latinoamericana de la Biogeografía. Las Prensa de Ciencias, Facultad de Ciencias, UNAM. México.

Kohlmann, B., J. Wilkinson, \& K. Lulla. 2002. Costa Rica desde el espacio. Universidad EARTH. San José, Costa Rica.

López-Ramos, E. 1980. Geología General y de México. V. 1-3. Publicaciones Secretaría de Educación Pública. México.

Malagón, D. (ed.) 1988. Suelos y bosques de Colombia. Instituto Geográfico Agustín Codazzi. Subdirección Agroecológica. Bogotá, Colombia.

Martínez, A., \& G. Halffter. 1972. New taxa of American Canthonina (Coleoptera, Scarabaeinae). Ent. Arb. Mus. Frey, 20 (1):33-66.

Martínez, A., G. Halffter, \& V. Halffter. 1964. Notas sobre el género Glaphyrocanthon (Coleoptera: Scarabaeinae: Canthonina). Acta Zool. Mex. (n.s.), 7 (3):1-42.

Martínez I., \& E. Montes de Oca. 1994. Observaciones sobre algunos factores microambientales y el ciclo biológico de dos especies de escarabajos rodadores (Coleoptera: Scarabaeidae: Canthon). Folia Entomol. Mex., 91:47-59.

Medina, C., A. Lopera-Toro, A. Vítolo, \& B. Gill. 2001. Escarabajos coprófagos (Coleoptera: Scarabaeidae: Scarabaeinae) de Colombia. Biota Colombiana, 2 (2):131-144.

Mendoza, C. H. 1999 Estructura y riqueza florística del bosque seco tropical en la región Caribe y el Valle del Río Magdalena, Colombia. Caldasia, 21 (1):70-94. 
Meschede, M., U. Barckhausen, \& H. U. Worm. 2000. Desarrollo del centro de dispersión entre las placas de Cocos y Nazca y los trazos de los puntos calientes. Rev. Geol. América Central, 23:5-16.

Molina, L. E. (ed.). 1996. Geomorfología y Aspectos Erosivos del Litoral Caribe Colombiano. INGEOMINAS. Cartagena, Colombia.

Montero, W. 2001. Neotectónica de la región central de Costa Rica: frontera oeste de la microplaca de Panamá. Rev. Geol. América Central. 24:29-56.

Morón, M. A. 1979. Fauna de Coleópteros Lamellicornios de la Estación Biológica Tropical Los Tuxtlas, Veracruz. An. Inst. Biol. UNAM., ser. Zoología, 1:375-454.

Morón, M. A, J. F. Camal, \& O. Canul. 1986. Análisis de la entomofauna necrófila del área norte de la Reserva de la Biosfera Sian Ka'an, Quintana Roo, México. Folia Entomol. Mex., 69:83-98.

Morón, M. A., C. Deloya, \& L. Delgado-Castillo. 1988. Fauna de coleópteros Melolonthidae, Scarabaeidae y Trogidae de la región de Chamela, Jalisco, México. Folia Entomol. Mex., 77:313-378.

Morón, M., \& R. Terrón. 1984. Distribución altitudinal de los insectos necrófilos en la sierra norte de Hidalgo, México. Acta Zool. Mex. (n.s.), 3:1-47.

Morón, M. A., F. J. Villalobos, \& C. Deloya. 1985. Fauna de Coleópteros Lamellicornios de Boca de Chajul, Chiapas, México. Folia Entomol. Mex., 66:57-118.

Neita, M. J., L. L. Pardo, M. D. Quinto, \& D. N. Cuesta. 2003. Los escarabajos copronecrófilos Coleoptera: Scarabaeidae en la parcela permanente de investigación en biodiversidad (PPIB) en Salero, Chocó. Pp. 79-90 In: F. G. Cossio, \& A. Ramos (eds.), Diversidad Biológica de un Bosque Pluvial Tropical. Universidad Tecnológica del Chocó. Instituto de Investigaciones Ambientales del Pacífico. Comunidad de Salero, Unión Panamericana, Chocó.

Nelson, C. E., \& F. Nietzen. 2000. Metalogenia de oro y cobre en América Central. Rev. Geol. América Central, 23:25-41.

Palacios-Ríos, M., V. Rico-Gray, \& E. Fuentes. 1990. Inventario preliminar de los Coleoptera Lamellicornia de la zona de Yaxchilán, Chiapas, México. Folia Entomol. Mex., 78:49-60.

París, G., \& J. A. Romero. 1994. Fallas activas en Colombia. Boletín geológico. INGEOMINAS, Bogotá, Colombia, 34 (2-3):1-53.

Platt J., B. Leyden, M. Salgado-Labouriau, W. M. Lewis, Jr., C. Schubert, M. W.Binford, D. G. Frey, D. R. Whitehead, \& F. H. Weibezahn. 1981. Late Quaternary Environmental History of Lake Valencia, Venezuela. Science, 214: 1299-1305.

Pulido, H. L. A., C. R. A. Riveros, H. F. Gast, \& P. von Hildebrand. 2003. Escarabajos coprófagos (Coleoptera: Scarabaeidae: Scarabaeinae) del Parque Nacional Natural Serranía de Chiribiquete, Caquetá, Colombia, Parte I. Pp. 51-58 In: G. Onore, P. Reyes-Castillo, \& M. Zunino (eds.), Escarabeidos de Latinoamérica: Estado del Conocimiento. Monografías Tercer Milenio, vol. 3, SEA, Zaragoza, Spain.

Quigley, M. F., \& W. J. Platt. 2003. Composition and structure of seasonally deciduous forest in the Americas. Ecol. Monogr., 73 (1):87-106.

Ramón, J. C., G. Vidal, A. Rosero, P. Gómez, \& H. Borja. 2001. Reevaluación del modelo geológico del Campo Tello (Valle Superior del Magdalena) y sus implicaciones en el programa de desarrollo. Geología Colombiana, 26:59-77.

Rich, P. V., \& T. H. Rich. 1983. The Central American dispersal route: biotic history and paleography. Pp. 12-34 In D. H. Janzen (ed.) Costa Rican Natural History. The University of Chicago Press, USA. 
Padilla-Gil \& Halffter: Biogeography of Canthonini in Mesoamerica and Colombia

Richardson, J. E., R. T. Pennington, T. D, Pennington, \& P. M. Hollingsworth. 2001. Rapid diversification of a species-rich genus of neotropical rain forest trees. Science, 293: 2242-2245.

Riedinger, M. A., M. Steinitz-Kannan, W. M. Last, \& M. Brenner. 2002. A 6100 ${ }^{14}$ Cyr record of El Niño activity from the Galapagos Islands. Journal of Paleolimnology, 27:1-7.

Rivera-Cervantes, L. E., \& G. Halffter. 1999. Monografía de las especies mexicanas de Canthon del subgénero Glaphyrocanthon (Coleoptera: Scarabaeidae: Scarabaeinae) Acta Zool. Mex. (n.s.), 77:23-150.

Rosen, B. R. 1988. From fossil to earth history: applied historical biogeography. Pp. 437-481 In: A. A. Myers, \& P. S. Giller (eds.), Analytical Biogeography. Chapman, \& Hall. London, UK.

Rubio, L. C., M. F. Mosquera, \& B. H. Aguilera. (eds.) 1977. Mapa hidrogeológico de Colombia. Escala: 1:3000 000. INGEOMINAS.

Rutz, L. M. 2002. Microsismicidad del noroeste del Bloque Jalisco (México). Aplicación a la sismotectónica y peligrosidad sísmica de la zona. Bachelor of Science Thesis. Universidad de Granada. Facultad de Ciencias. Spain.

Rzedowski, J. 1978. Vegetación de México. Editorial Limusa, México.

Rzedowski, J., R. Medina Lemos, \& G. Calderón de Rzedowski. 2005. Inventario del conocimiento taxonómico, así como de la diversidad y del endemismo regionales de las especies mexicanas de Bursera (Burseraceae). Acta Botánica Mexicana, 70:85-111.

Sabogal, C., \& L. Valerio. 1998. Forest composition, structure, and regeneration in a dry forest of the Nicaragua Pacific Coast. Pp. 187-212 In: F. Dallmeier, \& J. A. Comiskey (eds.), Forest Biodiversity in North, Central and South America, and the Caribbean: Research and Monitoring. UNESCO, París, \& Parthenon Publishing Group.

Sánchez, L., W. Martínez, \& J. Flórez. 1998. Mapa gravimétrico de Colombia. Anomalia total de Bouguer. Escala: 1: 2.000 000. Instituto Geográfico Agustín Codazzi (IGAC) Bogotá, Colombia.

Sánchez-Valbuena, H. A. (ed.) 1992. Atlas de Colombia. Instituto Geográfico Agustín Codazzi. Subdirección Geográfica. Santafé de Bogotá, Colombia.

Sarmiento, G. 1975. The dry plant formations of South America and their floristic conections. J. Biogeography, 2: 233-251.

Schmidt-Effing, R. 1980. El origen del istmo centroamericano como vínculo de dos continentes. Pp. 21-32 In: W. Zeil (ed.), Nuevos Resultados de la Investigación Geocientífica Alemana en Latinoamérica. Deutsche Forschungsgemein-schaft (DFG). Bonn, Germany.

SIEPAC. 2003. Términos de referencia sobre impactos transfronterizos y regionales del proyecto SIEPAC línea de transmisión en América Central. Comisión Holandesa de Desarrollo Ambiental. (www.iadb.org/regions/re2/siepac/cap6.pdf)

Solís, A., \& B. Kohlmann. 2002. El género Canthon (Coleoptera: Scarabaeidae) en Costa Rica. G. it. Ent., 10 (50):1-68.

Sommer-Cervantes, I., L. Flores-Delgadillo, \& M. Gutiérrez-Ruiz. 2003. Caracterización de los suelos de la Estación de Biología Tropical Los Tuxtlas. Pp. 17-67 In: J. AlvarezSánchez, \& E. Naranjo-García (eds.), Ecología del Suelo en la Selva Tropical Húmeda de México. Instituto de Ecología, A.C. y Universidad Nacional Autónoma de México.

Steig, E. J. 1999. Mid-Holocene climate change. Science, 286:1485-1487

Swofford, D. L. 2002. PAUP. Phylogenetic Analysis Using Parsimony, Version 4. Sinauer Associates, Sunderland, Massachusetts.

Taborda, A. B. 1950. Contribución al conocimiento de la geología del Tolima. INGEOMINAS. Laboratorio Nacional de Fomento Minero Ibagué, Tolima, Colombia. 
Trejo, I. 2005. Análisis de la diversidad de la selva baja caducifolia en México. Pp. 111-122 In: G. Halffter, J. Soberón, P. Koleff, \& A. Melic (eds.), Sobre Diversidad Biológica: El Significado de las Diversidades Alfa, Beta y Gama. Monografías Tercer Milenio, SEA, Vol. 4, Zaragoza, Spain.

Trejo, I., \& R. Dirzo. 2000. Deforestation of seasonally dry tropical forest: a national and local analysis in Mexico. Biol. Conserv., 94:133-142.

2002. Floristic diversity of Mexican seasonally dry tropical forest. Biodiversity and Conservation, 11:2063-2048.

Tudhope, A. W., C. P. Chilcott, M. T. McCulloch, E. R. Cook, J. Chappell, R. M. Ellam, D. W. Lea, J. M. Lough, \& G. B. Shimmieeld. 2001. Variability in the El Niño- Southern Oscillation through a Glacial-Interglacial Cycle. Science, 291:1511-1517.

Ujueta, G. 2003. La falla de Santa Marta-Bucaramanga no es una sola falla; son dos fallas diferentes: la falla de Santa Marta y la Falla de Bucaramanga. Geología Colombiana, 28:133-153.

Vásquez, M. A. 1983. Soils. Pp. 63-65. In: D. H. Janzen (ed.), Costa Rican Natural History, The University of Chicago Press. U.S.A.

Vulcano, M. A., \& F. S. Pereira. 1964. Catalogue of Canthonini (Col. Scarab.) inhabiting the western hemisphere. Ent. Arb. Mus. Frey., 15:570-685.

Zunino, M. 2005. Filogenia de áreas de distribución: algunas reflexiones teóricas. Acta Zool. Mex. (n. s.), 21 (1):115-118.

Recibido: 23 de marzo 2006

Aceptado: 29 de septiembre 2006 
Padilla-Gil \& Halffter: Biogeography of Canthonini in Mesoamerica and Colombia

\section{APPENDIX 1 \\ Scarabaeinae (Canthonini and other tribes) of the forests studied}

MEXICO, CHAMELA

Agamopus lampros Bates

Canthon corporali Balthasar

Canthon pacificus Rivera \& Halffter

Canthon cyanellus cyanellus LeConte

Canthon humectus riverai Halffter \& Halffter

Canthon indigaceus LeConte

Pseudocanthon perplexus (LeConte)

Deltochilum timidum Howden

Deltochilum gibbosum (Fabricius)

Phanaeus demon Laporte

Phanaeus furiosus Bates

Coprophanaeus pluto Harold

Digitonthophagus gazella (Fabricius)

Onthophagus landolti Harold

Onthophagus igualensis Bates

Onthophagus hoepfneri Harold

Canthidium sp.

Dichotomius colonicus (Say)

Dichotomius amplicollis (Harold)

Ateuchus rodriguezi (Borre)

Uroxys sp.

Copris lugubris Boheman

\section{PALO VERDE, COSTARICA}

Agamopus lampros Bates Canthon cyanellus sallei Harold

Canthon deyrollei Harold

Canthon euryscelis Bates

Canthon indigaceus chevrolati Harold

Canthon meridionalis (Martinez, Halffter \& Halffter)

Canthon morsei Howden

Canthon mutabilis Harold

Pseudocanthon perplexus (LeConte)

Deltochilum lobipes Bates

Malagoniella astyanax (Harold)

Phanaeus wagneri Harold

Phanaeus demon Laporte

Phanaeus eximius Bates

Coprophanaeus telamon (Erichson)

Coprophanaeus pluto (Harold)

Onthophagus acuminatus Harold 
Onthophagus championi Bates

Onthophagus landolti Harold

Onthophagus hoepfneri Harold

Onthophagus marginicollis Harold

Onthophagus batesi Howden \& Cartwright

Canthidium laetum Harold

Canthidium guanacaste Howden \& Gill

Dichotomius yucatanus (Bates)

Dichotomius centralis (Harold)

Dichotomius annae Kohlmann \& Solis

Ateuchus rodriguezi (Borre)

Copris lugubris Boheman

\section{COLOMBIA, CARIBE REGION}

\section{Zambrano}

Canthon cyanellus sallei Harold

Canthon juvencus Harold

Canthon lituratus (Germar)

Canthon septemmacutatus (Latreille)

Malagoniella astyanax (Harold)

Coprophanaeus jasius (Olivier)

Canthidium sp.

Dichotomius belus (Harold)

Onthophagus marginicollis Harold

Onthophagus lebasi Boucomont

Uroxys sp.

Eurysternus impressicollis Laporte

\section{Los Colorados}

Agamopus lampros Bates

Canthon aequinoctalis Harold

Canthon cyanellus sallei Harold

Canthon juvencus Harold

Canthon subhyallinus Harold

Coprophanaeus jasius (Olivier)

Diabroctis cadmus Harold

Phanaeus hermes Harold

Canthidium sp.

Dichotomius belus (Harold)

Onthophagus marginicollis Harold

Onthophagus lebasi Boucomont

Onthophagus sp.

Uroxys sp.

\section{Tierra Bomba}

Canthon cyanellus sallei Harold

Canthon juvencus Harold 
Padilla-Gil \& Halffter: Biogeography of Canthonini in Mesoamerica and Colombia

Canthon lituratus (Germar)

Diabroctis cadmus Harold

Canthidium sp.

Dichotomius belus (Harold)

Onthophagus marginicollis Harold

Onthophagus lebasi Boucomont

Onthophagus landolti Harold

Uroxys sp.

Eurysternus impressicollis Laporte

\section{Neguanje}

Canthon cyanellus sallei Harold

Canthon juvencus Harold

Canthon lituratus (Germar)

Phanaeus prasinus Harold

Canthidium sp.

Dichotomius belus (Harold)

Dichotomius sp.

Dichotomius sp.

Onthophagus marginicollis Harold

Onthophagus lebasi Boucomont

Onthophagus landolti Harold

Eurysternus impressicollis Laporte

Eurysternus caribaeus (Herbst)

\section{COLOMBIA, NORTH TOLIMA}

Canthon acutus Harold

Canthon aequinoctialis Harold

Canthon cyanellus sallei Harold

Canthon juvencus Harold

Canthon lituratus (Germar)

Canthon morsei Howden

Canthon mutabilis Harold

Canthon subhyalinus Harold

Malagoniella astyanax (Harold)

Phanaeus hermes Harold

Dichotomius belus (Harold)

Dichotomius sp. 1

Dichotomius sp. 2

Onthophagus landolti (Harold)

Onthophagus lebasi (Boucomont)

Onthophagus marginicollis (Harold)

Onthophagus rubrescens (Blanchard)

Canthidium sp.

Ateuchus sp.

Uroxys sp.

Canthidium sp.

Eurysternus plebejus (Harold) 
MEXICO, LOS TUXTLAS (for rainforest, M. Favila pers. com.)

\author{
Canthon euryscelis Bates \\ Canthon femoralis (Chevrolat) \\ Canthon morsei Howden \\ Canthon vazquezae (Martinez, Halffter \& Halffter) \\ Canthon subhyalinus Harold \\ Canthon edmondsi Rivera \& Halffter \\ Deltochilum scabriusculum Bates \\ Deltochilum pseudoparile Paulian \\ Delthochilum gibbosum sublaeve Bates \\ Phanaeus endymion Harold \\ Sulcophanaeus chryseicollis (Harold) \\ Onthophagus nasicornis Harold \\ Onthophagus rhinolophus Harold \\ Canthidium aff. ardens Bates \\ Canthidium centrale Boucomont \\ Canthidium aff. perceptibile Howden \& Young \\ Scatimus ovatus Harold \\ Uroxys boneti Pereira \& Halffter \\ Uroxys bidentis Howden \& Young \\ Uroxys transversifrons Howden \& Gill \\ Ontherus mexicanus Harold \\ Bdelyropsis newtoni Howden \\ Dichotomius satanas (Harold) \\ Copris laeviceps Harold \\ Eurysternus angustulus (Harold) \\ Eurysternus caribaeus (Herbst) \\ Eurysternus velutinus Bates
}

\title{
COLOMBIA, LETICIA
}

Canthon aequinoctialis Harold

Canthon fulgidus Redtenbacher

Canthon luteicollis Erichson

Canthon semiopacus Harold

Cryptocanthon peckrorum Howden

Canthonella n. sp.

Scybalocanthon sp.

Deltochilum amazonicum Bates

Deltochilum carinatum Westwood

Deltochilum sp. 1

Deltochilum sp. 2

Deltochilum sp. 3

Coprophanaeus telamon (Erichson)

Coprophanaeus n. sp.

Oxysternon conspicillatum (Weber) 
Padilla-Gil \& Halffter: Biogeography of Canthonini in Mesoamerica and Colombia

Oxysternon silenus Laporte

Phanaeus bispinus Bates

Phanaeus cambeforti Arnaud

Phanaeus chalcomelas (Perty)

Phanaeus meleagris Blanchard

Onthophagus haematopus Harold

Onthophagus sp. 1

Onthophagus sp. 2

Onthophagus sp. 3

Ontherus pubens Génier

Ontherus diabolicus Génier

Uroxys sp. 1

Uroxys sp. 2

Dichotomius boreus (Oliver)

Dichotomius mamillatus (Felsche)

Dichotomius ohausi (Luederwalt)

Dichotomius podalirius (Felsche)

Dichotomius sp. 1

Dichotomius sp. 2

Dichotomius sp. 3

Dichotomius sp. 4

Canthidium bicolor Bouc.

Canthidium gerstaeckeri Harold

Canthidium sp. 1

Canthidium sp. 2

Canthidium sp. 3

Canthidium sp. 4

Canthidium sp. 5

Bdelyrus sp.

Ateuchus murrayi (Harold)

Ateuchus sp. 1

Ateuchus sp. 2

Eurysternus caribaeus Herbst

Eurysternus cayennensis Laporte

Eurysternus confusus Jessop

Eurysternus foedus Guérin

Eurysternus hirtellus Dalman

Eurysternus inflexus (Germar)

Eurysternus velutinus Bates 